\title{
Strategic Application of the Tao 道 of Soft Power: The Key to Understanding China's Expanding Influence in Africa
}

\author{
Paul Nantulya \\ Research Associate; Africa Center for Strategic Studies, National Defense \\ University, $3005^{\text {th }}$ Avenue, Building 20, Fort Lesley J. McNair, \\ Washington, DC 20319-5o66, USA \\ paulnantulya@gmail.com
}

\begin{abstract}
Soft power has traditionally been viewed by China's leaders as a fulcrum of international competition. The foundations were laid in the 1990s by Jiang Zemin's Going Out Strategy (Chinese: 走出去战略; pinyin: Zǒuchūqū Zhànlüè) which encouraged Chinese enterprises to venture overseas to capture new markets. Soft power, however, has much older traditions dating back to the Warring States (Chinese: 戰國時代; pinyin: Zhànguó Shídài, $475^{-220} \mathrm{BC}$ ). It is from this era that China draws its theory and praxis of soft power, which it frames as "Cultural Soft Power," literally meaning "Civilizational Soft Power" (Chinese: 文化软实力; pinyin: wén huà ruăn shíli). Drawing mostly on Chinese philosophical and strategic thought, this paper discusses the conceptual bases of Chinese soft power, examines the values and tools that shape it, how they are applied in Africa, as well as their limitations. The study finds that "Cultural Soft Power" is the thrust behind China's strategic engagements in Africa which aim to generate sustained African support for Beijing's vision to transform global governance institutions and norms. The Confucian concepts of "appeal" and "attraction" are central to Chinese soft power thought which is premised on the assumed uniqueness of Chinese culture and civilization and therefore the Chinese development model. This lies at the heart of the ideological alternative China is promoting on the world stage and its approach to strategic competition. Africa is a vitally important foundation in this quest.
\end{abstract}




\section{Keywords}

China - Cultural Soft Power - appeal - attraction - Community of Common Destiny - China

Soft power has been the primary means through which China has interacted with Africa since the Tang Dynasty (618-907 AD). The ancient Silk Road, which extended from China to East Asia, Southern Europe, Persia, the Arabian Peninsula, and East Africa was the primary medium for these engagements. All Chinese dynasties used it to spread Chinese cultural influence and civilizational values. Two Confucian concepts shaped how the ancient Chinese thought about influence ( $\mathrm{Wu}, 2018)$. The first is “attractiveness" (Chinese: 吸引力; Pinyin: xīyı̌n li), or "attractive force." The second is "appealing power" (Chinese: 感召力; Pinyin: găn zhào li), meaning, “charisma” and “appeal.” These concepts are grounded in the longstanding Chinese proposition that China had a superior culture and norms that made it attractive and appealing to foreigners, so much so that it did not need to employ coercive measures to build influence.

The People's Republic of China (PRC) repackaged these ideas in its concept of the "Community with Shared Future for Mankind" (Chinese: 人类命 运共同体 Pinyin: Rénlèi mingyùn gòng tóng tǐ), translated as the "Community of Common Destiny." This is China's vision of an international society built on Chinese norms and institutions as an alternative to Western norms. It is anchored in the modern Silk Road known as One Belt One Road (Chinese: 一帶一路; Pinyin: ȳ̄ dài yı̄ lù) Beijing’s plan for a global economic architecture of roads, railways, ports, oil and gas pipelines, power plants, and digital and satellite communications with China at the center. One Belt One Road has been presented by Beijing as the latest form of its "attractive force" and "power of appeal" as 138 countries have signed on to it, making it the world's largest and most expensive multilateral program since the Marshall Plan and one of the clearest connections between China's ancient and contemporary initiatives (China National Development and Reform Commission, 2020).

Soft power is the ability to shape foreign audiences through appeal and attraction. It is contrasted with hard power that relies on force to generate influence. It was coined by American scholar Joseph Nye in his 1990 book titled

* Disclaimer: The views expressed in this article are those of the author and do not necessarily reflect the policy or position of the Africa Center for Strategic Studies. 
Bound to Lead: The Changing Nature of American Power. In it, he writes: "When one country gets others to want what it wants it might be called co-optive or soft power in contrast with the hard or command power of ordering others to do what it wants." (Nye, 1990: 10.) Nye's work found a receptive audience in China. Xie Tao (2015) noted that a search for "soft power" on CKN I - the world's largest digital compilation of Chinese language journal articles - generates 1,777 entries since 2000 (Xie, 2015). Furthermore, at least two dozen research centers and programs dedicated exclusively to studying soft power have been established since the Hu Jintao era, including an equal number within government and party affiliated think tanks. Against the backdrop of debates on soft power, General Secretary Hu Jintao promoted a vision of Chinese rejuvenation based on the attractiveness of Chinese culture. The Party Congress that elected his successor Xi Jinping in 2012 devoted an entire plenary session to "Cultural Soft Power" (Chinese: 文化软实力; Pinyin: wenhua ruanshili), literally meaning "Civilizational Soft Power." During the 18th Party Congress in 2014 Xi announced: "We should increase China's cultural soft power, give a good Chinese narrative, and better communicate China's messages to the world (Albert, 2018)."

China's strategic thinking goes back to ancient times. Produced in the late spring and early autumn periods, Sun Tzu Bing presented comprehensive planning and guidance on war. The term 'strategy' was first seen at the end of that century in the book 'strategy' written by Sima Yi.

Science of Military Strategy (2013 Edition) ${ }^{1}$

Science of Military Strategy, a product of the Academy of Military Science, the highest institute for military research in China, is the pinnacle of China's professional military literature on war and statecraft. It builds on other authoritative works including The Science of Campaigns (2006) and Campaign Stratagems (2002).

These works all place Chinese strategy within a body of thought rooted in the ideas of China's traditional philosophers, including Confucius, Mencius,

1 军事科学院军事战略研究部, 《战略学 2013 年版》(北京: 军事科学出版社, Academy of Military Science Strategic Research Department (2013), The Science of Military Strategy, 2013 Edition, Beijing, Academy of Military Science Press. 
Mozi, Shang Yang, and Lao Tzu. The first chapter of Science of Military Strategy states the following:

China's 5,000 year history forms a national cultural tradition with unique characteristics, including the benevolence in Confucianism, the conflict avoidance in Taoism, the diligence in Mohism, the stratagems of Chinese military science, and, the sizing up of political situations of the Chinese Legalist school of thought (2005: 18).

General Li Jijun, the former Vice President of the Academy of Military Science, suggests that a nation's strategic culture "cannot but bear the imprint of cultural traditions" (Jijun, 1997). Generals Peng Guangqian and Yao Youzhi, the drafters of the 2005 edition of Science of Military Strategy explain that strategic thought "is always formed on the basis of certain national cultural traditions and the formulation of strategy is always controlled by certain cultural ideologies and cultural complexes" (Guangqian and Youzhi, 2005: 12) Teijun Zhang (2012) notes: "Chinese scholars have frequently quoted the theories of traditional strategists like Sun Tzu in their analyses of China's security strategies" (p. 8). Yuan-kang Wang (2011) explains that: "China's modern strategists pay considerable attention to cultural soft power in military-strategic practice" (p. 28). General Li Jijun, when speaking to students at the U.S. Army War College in August 1997, advised that knowledge of Chinese culture and strategic thought were key to understanding how Chinese leaders think about statecraft (Jijun, 1997). He argued that China's major philosophies produced a uniquely Chinese strategic mindset that is deeply inclined to using cultural soft power rooted in civilizational values. In a 2013 speech to senior party leaders Xi Jinping said:

We should work hard to absorb the philosophical and moral essence of traditional Chinese culture, foster and disseminate our national character, and identify and explicate their essential features of benevolence, peopleorientation, integrity, righteousness, concordance, and common ground. JINPING, 2014

Colonel Peng Huaidong (2017) a senior scholar at the Academy of Military Science explained: "Western societies extol martial values, militarism, and violence, whereas Chinese society emphasizes peace, morality, balance, and intellectual rather than material strength" (p. 37).

Issued in July 2019, China's National Defense in the New Era, Beijing's latest strategic guidance, notes: 
The strategic decision to follow the path of peaceful development, the independent foreign policy of peace, and the best of cultural traditions considering peace and harmony as fundamentals - determine that China will pursue a national defense policy that is defensive in nature.

STATE COUNCIL INFORMATION OFFICE, 2019

This passage reflects the general Chinese obsession with "Cultural Soft Power" which China's leaders and top intellectuals view as fundamentally different from Western soft power due to its roots in Chinese philosophy of which Confucian principles are heavily pronounced. Confucianism rests on the belief that human beings are fundamentally good, teachable, and improvable through the self-cultivation of values, norms, and practices that model peace, harmony, morality, and temperance (Huaidong, 1997). This however does not necessarily translate into a commitment to pacifism. Andrew Scobell (2002: 34) argues that China has a dual strategic tradition consisting of a Confucian strand that is defensive-minded and conflict-averse, and an aggressive one that is focused on state power and favors military solutions (Scobell, 2002). Both influence each other dialectically to produce a "Chinese Cult of Defense" that "paradoxically predisposes Chinese leaders to pursue offensive military operations as a primary alternative while rationalizing these actions as being purely defensive" (Scobell, 2002: 35-40)

The dialectical interplay between hard and soft methods flows from the concept of Yin and Yang (Chinese: 阴阳; Pinyin: yinnyáng), literally meaning "negative, positive" or "dark, bright." Yinyáng thought is elemental to Chinese cultural beliefs. It views seemingly opposite forces as interconnected, and interdependent. Yin represents receptive qualities (soft, feminine, weak, yielding, and passive) while yáng represents the opposite (hard, male, strong, firm, and active). Tony Fang (2015) explains that: "Each quality contains at its core the element of its opposite and neither is superior nor inferior" (p. 3). Rather, an increase in one causes a corresponding decrease in the other thereby producing friction. This tension is resolved by blending the two sides in dialectical fashion so as to achieve harmony. The Peoples Liberation Army's (PLA) concept of the "three warfares theory" draws on this thinking ("P LA implements," 2020). It holds that some of the most pressing threats China faces occur in the realm of ideas, of which the most important elements are public opinion warfare, psychological warfare, and legal warfare (Mattis, 2018). The theory of victory in each of these domains depends on a sophisticated understanding of how soft power combines with hard power to produce outcomes favorable to the state. 


\subsection{Understanding the Chinese Strategic Mind}

Chinese theories of statecraft date back to the "Warring States Period" (Chinese: 戰國時代; Pinyin: Zhànguó Shídài, or “Era of the Warring States” (475-220 BC), a period of protracted warfare that ended in 221 BC when the state of Qin conquered and unified its rivals and established China's first imperial dynasty (Zhao, 2015). Qin is of particular significance in Chinese strategic thought as it gave China its modern name (Qin is pronounced "Chin") and many of its traditions. The "Warring States Period" is also known as the "Golden Age of Chinese Philosophy” (Chinese: 諸子百家; Pinyin: zhūž̌ bǎijiā), literally meaning “The One Hundred Schools of Thought," which is the bedrock of China's intellectual culture, philosophy, and theories of governance (Canterbury Classics, 2016). The strategic teachings of this era are contained in China's "Seven Military Classics” (Chinese: 武经七书; Pinyin: Wǔjing qi shū), a canonical anthology of works consisting of the following:

1. Sun Tzu's Art of War (Chinese: 孙子兵法; Pinyin: Sūnž̌ bingfă), meaning "Master Sun's Military Methods;"

2. Methods of the Sima (Chinese: 司马法; Pinyin: Sīmǎ Fǎ) or “The Marshall's Art of War;"

3. “The Three Strategies of Huang Shigong, (Chinese: 黄石公三略; Pinyin: Huáng Shígōng Sān Lüè), literally translated as "The Three Strategies of the Duke of Yellow Rock;"

4. On Questions and Replies between Tang Taizong and Li Weigong (Chinese: 唐太宗李卫公问对; Pinyin: Táng Tàizōng Ľ̌ Wèi Gōng Wèn Du), a collection of dialogues between Emperor Taizong (599-649 AD) of the Tang Dynasty and his top commander, Li Jing;

5. Wei Laozi (Chinese: 尉缭子; Pinyin: Wèi Liáozi), named for Wei Liao, a top advisor to the Qin state; and,

6. Wu Qi's Wuzi (Chinese: 吴子; Pinyin: Wúžr), a collection of ideas by Wu Qi, a military leader and philosopher from the Warring States Period. ${ }^{2}$ China's extensive corpus of strategic writings from the Warring States down to the Communist era draw on these Classics to produce a distinctively Chinese approach to strategy, or bingfă (Chinese: 兵法). Bìngfă is a key Chinese term that is commonly translated as "methods of managing soldiers." However it can also be translated as "the art of managing organizations and relations between organizations" (Jones, 2012). Its most important intellectual premise is that war is not restricted to physical battle or displays of military force.

2 For the most comprehensive discussion of these classics that is available to non-Chinese speakers, see Sawyer (1993) The Seven Military Classics of Ancient China. Basic Books. 
Rather, it extends to culture, diplomacy, politics, trade, and the "battle of ideas" (Barker, 2017). The skillful strategist in this view outmaneuvers rivals without using military power.

This is captured in chapter three of Sun Tzu's Art of War that states: "Hence to fight and conquer in all your battles is not supreme excellence; supreme excellence consists in breaking the enemy's resistance without fighting" (Sawyer, 1993: 16). In chapter five it notes: "In all fighting, the direct method is used for joining battle, but indirect methods are needed to secure victory. Indirect strategies, efficiently applied, are inexhaustible as heaven and earth" (Sawyer, 1993: 19-25).

The Tao Te Ching, one of China's most important religious and philosophical texts notes:

The most yielding thing in the world will overcome the most rigid. When life begins, we are tender and weak; when it ends we are brittle and hard, so the soft and supple are the companions of life, while the stiff and unyielding are the companions of death.

LIU, 2015: 3

Mao Zedong, the founder of the People's Republic of China drew heavily on China's philosophical works in developing the theoretical foundations of the party and military. The guiding framework of his work on military doctrine, titled On Protracted War, is captured below:

Weapons are an important factor in war, but not decisive; it is people, not things that are decisive. The contest of strength is not just a contest of military and economic power; it is also a contest of human power and morale.

ZEDONG, 1960: 3

Such interpretations of strategy reflect the wider context in which Chinese strategic thinking evolved. The Warring States were characterized by protracted wars with no clear winners. Overtime, military leaders employed nonmilitary techniques to outwit their opponents instead of relying solely on military power. Eventually an indirect approach to warfare emerged that put a premium on non-military methods to reinforce military objectives (Sawyer, 1996). The battles described in the Seven Military Classics contain a trove of highly unorthodox methods that became a staple of the Chinese tradition of war which lives on in the People's Liberation Army doctrine. In 228 BC, the Qin forces precipitated the collapse of a much larger Zhao army by conducting a 
sustained propaganda campaign to discredit its commander and create a mutiny within its ranks. To curb the unrest, the King had the Zhao commander arrested and executed but this led to more divisions that Qin forces exploited to secure victory (Li and Zheng, 2001).

Zhao forces used subterfuge to secure victory over the Xiaognu tribes many years later in 256 в С. They responded to a Xiaognu advance by withdrawing all their forces from the border to feign weakness. To complete the ruse, farmers were sent to cultivate their fields seemingly oblivious to the threat. Sensing an easy victory, the Xiaognu forces launched a massive assault but were soon surrounded and annihilated by Zhao units that had been secretly deployed behind their lines (Sawyer, 1996). In 225 BC, Qin forces defeated the Wei state by digging a series of canals that diverted waters from the Yellow River into the city of Daliang while holding it under siege. This led to massive flooding that killed more than 100,000 civilians, ultimately forcing the troops to surrender (Nantulya, 2016). Virtually all Chinese military texts from this point on extol the use of unorthodox methods, ponder the role of soft power, and articulate a wide body of measures aimed at securing victory through the interplay of direct and indirect tactics. As explained in the Six Secret Teachings:

Employing subterfuge and psychological techniques allows manipulation of the enemy and hastens its demise. Commanders must seek to achieve victory via wit, preferably without actually fighting. The commander must outwit enemies through diplomacy and manipulation.

SAWYER AND SAWYER, 2OO9: 32-41

The seminal Confucian text, Xunzi (Chinese: 荀子; Pinyin: Xúnzì) literally meaning "The Writings of Master Xun" notes:

One who knows the way of true strength does not rely on military strength along. Rather, he considers how to use a King's mandate as a means to collect together his physical power and consolidate his inner power.

HUTTON, 2004: 13

The theory of "Peoples War" which is described by the PLA as its "fundamental strategy" states:

The practice of people's warfare under new conditions involves the Party, government, military and civilian. It involves political, economic, scientific and technological, military, diplomatic, educational and cultural and 
other areas. The strength of a nation's defense is not simply determined by its armed forces.

GUANGQIAN, 1998: 13

Such thinking was also heavily influenced by China's traditional philosophers, including Confucius, Mencius, Shang Yang, and Xunzi. Notably, China's philosophers were not merely detached observers; they advised emperors and senior political and military leaders, contributing to shaping strategy. Confucianism was adopted as the China's official state ideology from the Han Dynasty (206 BC-220 AD) to the Qing Dynasty (1636-1912) (Liu, 2015). For over 2,ooo years appointments to the Chinese government were based on imperial civil service examinations (Chinese 科举; Pinyin: $k \bar{e} j u \breve{u}$ ) that determined one's proficiency in Confucian ideology, principles, and governance practices (Ho, 1962). This partly explains the profound ideological influence that traditional Chinese philosophies have had on contemporary Chinese strategic thought.

\subsection{China's Philosophical Revival}

Ironically, the Communist Party of China (CPC) once viewed traditional Chinese philosophy as an ideological threat to its hold on power. In 1966 it launched a "Cultural Revolution" to purge Chinese society of "backward" traditional practices, causing widespread social upheaval and leading to the deaths of close to 8 million people according to many Chinese writers of that era (Jung, 1961). However Chinese philosophies made a dramatic comeback during the 199 os as part of the post-revolutionary reforms undertaken by Deng Xiaoping. In 2016, the Communist Party broke its silence on the "Cultural Revolution," declaring that: "History had shown that the 'Cultural Revolution' was utterly wrong, in both theory and practice" (Phillips, 2016).

While the revitalization of China's traditional philosophies appeared to signal a change of heart towards allowing popular expression, it actually served utilitarian political purposes. As Ralph Sawyer (2006) observed, it was meant for domestic and foreign consumption; domestically to reinforce Confucian mechanisms of respect for authority and hierarchy, and externally to play up the international perception of Confucianism and Taoism in particular as uniquely pacifist traditions (Sawyer, 2006). Moreover the party understood that China's philosophical traditions were too deep to be uprooted and could therefore fill the vacuum created by the decline of Maoist ideology.

The resurgence of Confucianism in particular went hand in hand with the revival of Legalism (Chinese: 法家; Pinyin: Făjiā) or the "Legalist School of Thought of the Warring States Period," which was the official ideology of the 
Qin state (Yuri, 2006). Legalism developed in direct opposition to Confucian and Mencian teachings. It holds that human beings are motivated by selfinterest and that social stability depended on iron discipline, vigorous state control, centralized rule, complete obedience to authority, and a rigid system of laws based on rewards and harsh punishments (Yuri, 2006). Furthermore, all human activity should be directed towards "building a strong state and powerful army" (Chinese: 富國強兵; Pinyin: fú guó qiáng bìng).

This is summed up by Shang Yang (2015), a contemporary of Confucius, who said: "When the sage rules the state, he is able to consolidate force and spend force; hence, he who rules the state well consolidates force to attain a rich country and strong army" (p. 29)

China's vast mechanisms of social control, discipline, and extensive power are more in line with Legalist teachings than Confucianism. This is confirmed in the guiding resolution of the 19th Party Congress in 2017 which states: "The party leads everything: government, army, people, and scholars; it is the most exalted force of political leadership" ("Full text of Xi Jinping's report", 2011). Will Green (2020) a close observer of China/Africa relations said: "There are a number of synergies between Legalism and the CCP; Mao himself was an avid admirer of Qin Shihuang [the emperor of China's first imperial dynasty]" (Green, 2020). The CPC's operational methods of exerting sustained control over its 19 million members, the state, and China's two and a half million strong military, are essential components of a Legalist legacy that has enhanced its survival and continued dominance and is more in line with coercive, or hard power than soft power. Many African ruling parties find this attractive, particularly those preoccupied with regime survival. It constitutes a different type of ideological appeal of the Chinese model that is instilled through several soft-power activities such as party-to-party and leadership training, technical assistance, and exchange programs. The CPC trains more African politicians, party leaders, and cadres than any other political party in the world, contributing significantly to the political development and governance patterns on the continent. This has opened up more avenues for China to build influence, offer governance models and techniques, and enhance relationships (Li, 2015).

\subsection{Tao 道 of Soft Power Attraction: Historical and Contemporary Linkages}

The tao (meaning the way) of attraction is rooted in the cultural belief that China's civilizational legacy offers something unique to mankind. One of China's top diplomatic point men, Yang Jiechi, has argued that China has tapped "into the rich heritage of governance philosophy and wisdom unique to Chinese culture that is relevant today and given full expression to the shared 
aspirations of both the Chinese people and the people around the world" (Jiechi, 2017). This echoes Xi Jinping's address to the 95th Anniversary of the founding of the CPC in July 2016 which pledged to "contribute Chinese wisdom to global governance." He also announced that the Chinese people were "fully confident of providing solutions to mankind's exploration of social systems." ("China to contribute", 2016).

The notion of China's special place in the world comes from a particular reading of Chinese history that China's leaders use to frame their political aims. The Mandarin name for China is Zhōngguó, depicted by the characters 中國 which literally translates to "Center of the Universe" (China's official name). China is also called Zhōnghuá, (中華), or “Central Beauty," (Huáxià, 華夏) or "Beautiful Goodness," and Shénzhōu 神州), meaning "Divine State." From the Shang Dynasty (1556 to 1046 вС) to the Qing (1644-1912) China called itself the "Middle Kingdom" (or "Central Country") and saw itself at the center of a Sinocentric world consisting of "inner and outer realms" (China and its immediate periphery), tributary states (such as Vietnam, Burma, and Korea), and "outside peoples" (traditionally described as "barbarians.") (Wei-Ming, 1991).

China's rulers took it for granted that their culture was the standard to which others aspired, so much so that outsiders and even enemies adopted them as a sign of their own legitimacy (Spence, 2011). Many Chinese contemporary political scientists argue that the appeal and pull of Chinese culture and civilizational values set China apart from Western worldviews, pointing out that while the great empires like Rome and Britain used military power to expand outward, Chinese empires used culture as a focal point and drew the surrounding people inward (Yang Yue Heng, 202O).

Several critical periods in Chinese history have lent weight to this argument. For example when China was invaded by Mongols in 1205 and the Manchu in 1618, the dynasties they established (Yuan and Qing respectively) adopted preexisting Chinese norms, traditions, language, and institutions to legitimize their rule. Yuan and Qing are also considered to be among China's greatest dynasties (the latter expanded China's borders to their greatest extent) (Fu, 2011). The fact that these "Northern Barbarians" (Chinese: 北狄; Pinyin: $b e ̌ i ~ D \imath \imath$ as they were described, saw it fit to adopt Chinese ways is held up as proof of the inherent appeal of Chinese culture. This is captured in the Confucian saying: "I have heard of the huáxià (Chinese) converting barbarians to their ways but never of their being converted to barbarian ways" (Zhi, 2004: 6). The assumed superiority of Chinese culture was also reinforced by China's tributary system (Chinese: 朝贡体制: Pinyin: cháo gòng ť zhi), meaning "To give tribute to the Emperor." This system of international relations was operational throughout most of Southeast Asia for around 2,00o years until 
the early 19th Century. It consisted of highly regulated international exchanges in which the Sinicized societies on China's periphery formally acknowledged the superiority of Chinese culture and the authority of China's imperial court in exchange for Chinese protection and preferential access to the Chinese economy (Zhi, 2004).

These historical antecedents find modern expression in the concept of “Great Rejuvenation of the Chinese Nation," (Chinese: 中华民族伟大复兴: Pinyin: Zhōng huá mín zú wěi dà fù xìng), literally, "The Chinese people will revive China in a grand way that will be worthy of the greatest admiration." While this concept is widely associated with Xi Jinping, it actually dates back to Mao Zedong and has been coined differently by successive CPC leaders without losing its original meaning. The Xi administration has provided it content by setting specific deadlines. 2020 was set as the year when China would double its 2010 gross domestic product (GDP) to $\$ 13$ trillion to attain a "moderately prosperous society" and when the PLA would achieve full mechanization. Both goals were achieved in February 2020. The next deadline has been set for 2025 when China hopes to attain global dominance in high-tech manufacturing. In 2035, the PLA is expected to become a fully modernized force and a world leader in artificial intelligence. 2049, which marks the centenary of the Peoples Republic of China, is the date when China hopes to be a "world class power" in economic and military terms (Matanda, 2019). As Beijing inches closer to these milestones, it is also vigorously championing new global norms and institutions to create a conducive environment for its resurgence. The 2019 White Paper on China and the World in a New Era states:

We will actively promote innovative ideas in global governance, and explore values in our cultural tradition that remain relevant today as positive guides for good relations, trying to contribute Chinese wisdom, solutions and strength to global governance.

STATE COUNCIL INFORMATION OFFICE

\subsection{Major Schools of Chinese Soft Power Thought}

Joseph Nye's Bound to Lead was first re-published in China by the PLA with the provocative title: "Will America Be Able to Lead the World Once and for All?" (Chinese: 美國定能領導世界嗎; Pinyin: Měiguó ding néng lingdăo shì jiè ma) (1992). ${ }^{3}$ It concluded that Nye's ideas provided strategic options for America

3 奈, 美国定能领导世界吗, 军事译文出版社, 1992 [America Joseph Nye, Can America Lead the World? Military Translation Publishing House]. 
to "promote peaceful evolution to overthrow socialist and third world countries and reconfigure them in its image and along Western models" (Military Translation Publishing House, 1992: 10-14). Nye's thesis on soft power was viewed in this sense as an American weapon that could be used to infiltrate Western ideas into China to subvert and overthrow the regime. This pessimistic outlook was heightened by the raging debates in the U.S. at the time about how long the CPC could survive after the collapse of the Soviet bloc (Zegart, 2019). The tone of these debates convinced China's leaders that the West was banking on China's collapse and planning to wield its soft power resources to bring this about. In 1992 the CPC established a study group on "Deepening Culture System Reform" (Chinese: 文化体制改革; Pinyin: wénhuà tǐ zhi găi gé), to discuss this perceived challenge (Keane and Jung Zhao, 2014).

In 1993, Wang Huning, then a scholar with Communist Party links published a paper on "Culture as National Power: Soft Power" (Chinese: 作为国i实力的 文化: 软权力; Pinyin: zuò wéi guójiā shí li de wén huà ruăn quán lì), as an answer to the party's query and a response to Nye's thesis on soft power (Huning, 1993). It made two arguments. First, soft power provided unique opportunities to wage ideological and political warfare and spread China's influence without using military force. Second, culture was the key to fostering domestic cohesion, legitimacy, and harmony while increasing the state's appeal and attraction overseas (Huning, 1993). These ideas represent the mainstream school of thought on soft power in China, commonly known as the "Culture School" or "Shanghai School" given their association with the Shanghai Institute for International Studies. Yu Xintian the director of this institute explains: "Soft power consists of ideas and principles, institutions and policy measures that operate within the nation's culture and cannot be separated" (Xintian, 2008, p. 11). Adherents of this school believe that China's overseas soft power campaigns should focus on the intensive promotion of Chinese culture to improve Beijing's global "appeal" and "attraction." The rapid spread of Confucius Institutes around the world is a direct outcome of this thinking.

The second dominant school of thought (sometimes called the Political School) accepts the arguments of the Culture School but adds that political power is the core of soft power. One of its key proponents, Yan Xuedong (2001), argues that imbalances between China's enormous material power and its soft power can hinder efforts to win genuine friendships (Xuetong, 2001). China should thus focus its soft power on strengthening overseas solidarity, building a harmonious society at home, and reforming its social institutions (Xuetong, 2001). This borrows heavily from "Harmonious Society" and "Harmonious World" the Confucian-based doctrines that guided China's domestic and foreign policies under the Hu Jintao government (Xuetong, 2001). 
Xin Li (2014) argues that China should develop a more integrative framework of soft power that includes formal, economic, and cultural diplomatic work (Li and Worm, 2010). Wang Yiwei (2008) suggests that public diplomacy should be more closely integrated with soft power campaigns (Wang, 2008: 26o). A third school of thought has emerged in recent years that supports the idea that China's soft power should focus on the goal of transforming the structures of the current international system to facilitate China's resurgence as a Great Power (Chinese: 世界强国; Pinyin: shi jiè qiáng guó) (Jiechi, 2019). The slogan of "Chinese Solutions," (Chinese: 中国方案, Pinyin:Zhōng guó fäng àn) is central to many of the narratives promoted by this school. It is built on the idea that Chinese models and norms offer viable alternatives to the West, echoing many of the underlying assumptions of China's recent foreign policy concepts such as the "Community of Common Destiny."

Zhao Tingyang (2005) of the Chinese Academy of Social Sciences is the most prominent proponent of this school. His 2005 book, The Tianxia System: An Introduction to the Philosophy of a World Institution and his 2009 work, A Possible World of All-Under-Heaven System, make a strong case for the construction of a new international society known as tiānxià (Chinese: 天下) or "All Under Heaven." The concept of tiānxià dates back to the Zhou Dynasty (1056-256 BC), China's longest reigning empire. According to its tenets, Chinese rulers derived their legitimacy from the "Mandate of Heaven" (Chinese: 天命: Pinyin: Tiänming), and were expected to maintain it by governing in line with Confucian principles of morality, harmony, and balance (Szczepanski, 2015). This philosophical idea was inherited by subsequent dynasties and remained operational as a core political concept until the collapse of the Qing dynasty in 1912. Zhao's other 2009 book, Investigations of the Bad World: Political Philosophy as the First Philosophy describes the prevailing international system as a "Hobbesian chaos rife with imbalance, disharmony, inequality, and clashes" (Tingyang, 2009). He proposes a different international system rooted in "the ancient Chinese concept of tiānxià." "I can think of no better overarching concept for governing our present world, which is, more than ever, an interdependence of plural identities," he explains (Tiangyang, 2018). "Today's chaotic world is in need of a new all under heaven" (Tiangyang, 2018).

\subsection{From Intellectual Thought to Strategic Policy}

China's leaders paid very close attention to Chinese soft power debates. In 1995 General Secretary Jiang Zemin tapped Wang Huning to lead the political unit of the Communist Party's Central Policy Research Office (CPRO) (Nantulya, 2012). Under General Secretary Hu Jintao, he took over as head of CPRO and became a full member of the Party Central Committee. He drafted China's 
core signature policies: Jiang Zemin's “Theory of Three Represents," Hu Jintao's "Scientific Development Perspective," and Xi Jinping's "Chinese Dream of the Great Rejuvenation of China" (Lo, 2017). Soft power was enshrined as a strategic policy objective at the 16th Communist Party Congress in October 2002. The then propaganda chief, Liu Yunshan called on the party leadership to enhance China's "Cultural Power," telling delegates that: "The power of culture is becoming an important component in integrating national power and international competitiveness ... China must turn itself into a 'cultural power" (Yunshan, 2002). Liu went on to become a member of the Politburo Standing Committee in addition to serving as President of the Central Party School.

On the eve of China's Five Year Plan review in 2006, General Secretary Hu Jintao declared: "The one who takes a commanding point on the battlefield of cultural development will gain the upper hand in fierce international competition" ("Hu Jintao speech", 2006). Wang Huning's thesis on "Cultural Soft Power" was adopted at the 17th Party Congress in October 2007. The perceived threat of Western "cultural hegemony" was high on the agenda. Li Shulei, a delegate at the gathering summed up the mood of the Congress as follows:

Culture is first and foremost an expression of our souls and emotions, our spiritual home. But to speak plainly some powerful foreign nations wish to use culture as a weapon against other nations, and for this reason we must work hard to raise our country's soft power.

"Soft power," 2020

This echoed Hu Jintao's political work report to this Congress which stated that:

In the present era, culture has increasingly become an important factor in the competition of overall national strength; we must stimulate the cultural creativity of the whole nation and enhance culture as part of the soft power of our country.

"Full report", 2007

In 2012, Wang Huning became General Secretary Xi Jinping's top foreign policy advisor and speech writer. In 2017, he joined China's highest leadership body, the six-member Politburo Standing Committee, putting him in a strategic position to take China's soft power to the next level. Under his watch, China's signature policies have been infused with ideas from China's dominant schools of soft power (Tobin, 2018). Their common unifying thesis rests on the notion that China should have the confidence to usher in a new era in human civilization 
thanks to the "depths of the Chinese cultural tradition" to paraphrase China's foreign policy czar, Yang Jiechi (Finish Institute of International Affairs, 2018).

Comprehensive National Power (CNP) (Chinese: 综合国力; Pinyin: Zōnghé guóli) is another key Chinese concept that underscores the importance of soft power in Chinese strategy. It was developed in the mid-199os as a planning tool to measure China's power capabilities relative to its peers and competitors. Unlike Western measurement tools CNP includes cultural appeal, ideology, historic traditions, media outreach, intellectual capabilities, and education as measurable sources of power (Zhang, 2010). All CNP indicators published in the 199os by the Academy of Military Science, Chinese Academy of Social Sciences, and China Institutes of Contemporary International Relations of the Ministry of State Security, China's foreign intelligence agency, rank China behind the U.S., including in soft power (no assessments have been published since 2010) (Ghosh, 2009).

However, all these institutes concluded that U.S. power would be on the decline by 2020 and that China and the Asia-Pacific countries would be on the ascendant. These assessments have contributed in part to the narratives of China's resurgence and America's diminishing influence that have become emblematic of China's strategic long-term analysis as reflected in government and party think tanks. They also contribute to the indicators of strategic competition that drive China's foreign policy. For example by 2010, China had launched more multilateral organizations than other UN Security Council members combined (Ikenberry and Lim, 2007). By 2012, it had the world's largest high-speed railway network and was involved in more overseas railway projects than any other country (U.S. China Economic and Security Review Commission, 2017). In 2016, it signed a landmark agreement with the African Union to connect all of Africa's borders with high-speed rail by 2063 (African Union Commission, 2016). By 2018 it had spent $\$ 156$ billion on regional connectivity projects in Africa and Asia (Albert, 2018). In 2019 it surpassed the U.S. in terms of the size of its diplomatic network, with 276 missions compared to America's 273 (Doherty, 2019).

By 2018 China has doubled the size of its foreign affairs budget to $\$ 9.49$ billion, a 15.6 percent increase from 2017 and 40 percent higher than when Xi Jinping took office in 2012 (Legarda, 2018). By contrast the U.S. foreign affairs budget request that year represented a 29.1 percent decrease from 2017 (Legarda, 2018). China in addition spends about $\$ 10$ billion annually on public diplomacy (Shambaugh, 2015). American spending by comparison does not reach the $\$ 1$ billion mark in any given year. In 2019 the U.S. Congress appropriated $\$ 730$ million on culture and education exchanges which was $\$ 420$ million above President Trump's request. Still, this is way below China's spending 
levels on such initiatives (Gramer and Lynch, 2009). Indeed, by 2020 China had established more than 5 oo Confucius Institutes globally compared to 245 U.S.-funded American Corners (Albert, 2018). These figures and trends underscore China's calculative and highly competitive soft power approach which is increasingly being framed in terms of expanding China's influence against the perceived decline of American leadership. Xi Jinping alluded to this at the 19th Communist Party Congress in 2017 when he said that: "China has entered a period of strategic opportunity; this will be an era that sees China moving closer to center stage and making greater contributions to mankind" ("Full text of Xi Jinping's report", 2017).

\section{Chinese Soft Power in Action in Africa}

In the 15th century, Zheng He, the well-known Chinese navigator of that time, led fleets to the east coast of Africa four times, and visited places in Somalia and Kenya of today. Even now, the relics of the crew of Chinese fleets can still be found in Kenya. ${ }^{4}$

LIU GUIJIN, Former Special Representative of the Chinese Government on African Affairs

China's leaders often invoke the memory of Zheng He, an admiral of the Ming Dynasty (1368-1644) as a symbol of China/Africa relations. He led seven voyages around the world between 1405 and 1433 to expand China's trade and cultural influence, establishing links with Mogadishu (Somalia) Kilwa and Zanzibar (Tanzania) Malindi, Lamu, and Mombasa (Kenya) and Quelimane (Mozambique) (Zhang, 2008). China's 21st Maritime Silk Road (Chinese: 21 世纪海上丝绸之路: Pinyin: 21 shìji hăi shàng sī chóu zhī lù), the sea-based leg of One Belt and Road, connects to Africa through the very same ports, drawing a direct line from the past to the present (Murphy, 2010). It starts in Mombasa on the Madaraka Express, one of China's flagship railway projects in East Africa. From there it extends to Naivasha, on the floor of the Great African Rift Valley and will eventually connect Uganda, South Sudan, the Democratic Republic of Congo, Rwanda, Burundi and Ethiopia to the Indian Ocean. Another Chinese-built railway connects land-locked Ethiopia to Djibouti's Doraleh Multipurpose Port built by the China Merchants Group.

4 Embassy of the Peoples Republic of China to Kenya (2016, October 16), Ambassador Liu Guijin: China is Not and Will Never Be a "Neocolonialist" in Africa, Chinese Mission, Retrieved August 17, 2020 from http://za.china-embassy.org/eng/zt/ask/t276318.htm. 
From there, the East Africa Belt and Road crosses the Suez Canal and bends west to connect a string of finished and planned Chinese port clusters in Mauritania, Senegal, Ghana, Nigeria, Gambia, Guinea, São Tomé and Príncipe, Cameroon, Angola, and Namibia. The third arc of this corridor travels north from Walvis Bay in Namibia to ports in Mozambique, Tanzania, and Kenya before connecting to Gwadar and Hanbantota ports in Pakistan and Sri Lanka (Nantulya, 2019). One Belt One Road is more than just a collection of massive infrastructure connections however. State Councilor and Foreign Minister, Wang Yi has described it as a mechanism for people-to-people and cultural exchanges while Xi Jinping has said it is one of the building blocks of the "Community of Common Destiny" ("New starting point", 2019).

The Zheng He narrative is also aimed at promoting the image of China's "Peaceful Rise" to counter the "China threat theory" that China's leaders say is prevalent in the West. Xi Jinping, at the Second Belt and Road Forum in October 2019, called Zheng He "a friendly emissary who built a bridge for East-West cooperation" ("President Xi proclaims", 2019). Xu Zuyuan, China's former Vice Minister of Communications explains that Zheng He "did not occupy a single piece of land, establish any fortresses, or seize any wealth" (Zhang, 2002). "Hegemonism is at odds with our cultural traditions," said former Premier Wen Jiabao (Zhang, 2002). The underlying message behind these narratives is that China will not dominate weaker countries despite its growing power (Lexiong, 200o). As evidence, China's leaders point to the fact that China, always true to its pacifist traditions, never held any colonies during the height of its power. However many Western observers question China's implied proclivity for pacifism. Australian Sinologist Geoff Wade argues that far from being peaceful, Zheng He's voyages used force to establish Chinese dominance in places like Sri Lanka and Vietnam (Wade, 2005). Retired U.S. Rear Admiral, Eric Mc Vadon notes: "Regardless of the Admiral's supposed goodwill, hundreds of warships and tens of thousands of soldiers could not have been received as sanguinely by China's neighbors." (McVadon, 2011: 46) And former U.S. Defense Secretary, James Mattis said, "The Ming Dynasty appears to be their model, albeit in a more muscular manner, demanding other nations become tribute states, kowtowing to Beijing; espousing One Belt, One Road" (Taylor, 2019).

Ralph Sawyer (2006) notes that while Chinese culture does indeed place great admiration for individuals whose behavior exemplifies Confucian principles, it also esteems strength, great fighters, and deep martial traditions (Sawyer, 2006). Moreover, far from being docile, pacifist, and passive, the Chinese society has experienced countless, long-running rebellions and violence on a monumental scale, leading to the toppling of at least a dozen dynasties. The connotation that force was never employed outside the empire's borders is 
also problematic according to Sawyer as China frequently launched aggressive military assaults against societies on its periphery and foreign states. These campaigns have been accorded a prominent place in dynastic and contemporary texts, including publications of the PLA's Academy of Military Science (Sawyer, 2006). Beijing however vigorously rejects commentaries and analyses that appear to question its narrative of "Peaceful Rise." China's 2006 "Policy on Peaceful Development Road," states that: "Zheng He took with him the cream of the Chinese culture and technology and a message of peace and friendship" (State Council Information Office, 2005). China's 2019 Defense White Paper notes: "China has grown from a poor and weak country to be the second largest economy neither by receiving handouts nor colonial plunder" ("Full Text: China's national defense", 2019). In summary, China wants its audiences to believe it will always conduct itself as a "responsible great power" or zé rèn dà guó (Chinese: 责任大国).

\subsection{Strategic Framing of Chinese Soft Power Campaigns in Africa}

China's leaders have concluded that Beijing's re-emergence on the world stage requires major investments in its soft power to build a favorable national and international image. As Ondřej Klimeš (2017) argues, the Communist Party of China "considers domestic cultural security and international soft-powerbuilding a single ideational and discursive enterprise designed to maintain its rule and gain international acknowledgement for it." Furthermore, the implied "uniqueness of China's culture and civilization, and, therefore, the China development model, is the main argument of this discourse" (Klimeš, 2018). These features of Chinese statecraft are evident in the patterns of China's soft power campaigns in Africa, which are characterized by three key features, 1) Blending hard and soft power, 2) Generating sustained support for China's vision of transforming global governance, and 3) Soliciting African support in promoting alternative models and development paths.

\subsection{Blending Hard and Soft Power}

China's strategic behavior in Africa reflects a calculative approach that mixes commercial, economic, and political interests in ways that downplay military and strategic interests. This has helped amplify its soft power while portraying its hard power as benign. African commentators for instance tend to associate the PLA's presence with international anti-piracy operations, peacekeeping, humanitarian operations, and citizen evacuation, which are considered legitimate and respectful of international law, an image the PLA constantly portrays in its communications (Yang and Jingyi, 2019). This also applies to perceptions about the PLA's first overseas naval base in Djibouti. It was built simultaneously 
with the Doraleh Multipurpose Port and was opened two months after this port started operations. China justified it in terms of its international obligations such as humanitarian operations and promoting peace and security in Africa which is how most African journalists also describe it (Wang, 2018). However, the PLA has also been employed to secure hard power objectives such as surveillance and intelligence collection, conducting naval and land exercises with African troops, gaining operational experience in overseas operations, and extending China's power projection capabilities. Furthermore, PLA Navy assets directly support the security elements of the Belt and Road, including protecting Chinese commercial vessels transiting African waters, a task that is also supported by select Chinese security contractors expressly authorized by the PLA. These aspects of Chinese military engagement rarely come to the public's attention, explaining why the PLA continues to be viewed in a fairly innocuous and uncontroversial light on the continent.

This has also been evident in the peacekeeping arena. China began courting Africa's troop contributors in the mid-2ooos having overcome its long-standing misgivings about UN peacekeeping which it tended to view as an extension of Western influence. China was deliberate in how it engaged African countries on this issue. Africa hosts the largest number of multilateral peace operations in the world, accounting for 75 percent of all deployed peacekeeping personnel (Holt and Shanahan, 2005). Furthermore, the vast majority of troops deployed in the UN's worldwide peace operations are from Africa (Campbell, 2018). Given this dynamic, Beijing concluded that Africa provided a path to build its credentials as a leader in international peace and security and extend its influence on the global stage. In 2009, China established a modern peacekeeping training center in Beijing's Hairou district and began training African peacekeepers. In 2015, it joined the UN's Peacekeeping Standby Readiness System, a decision applauded by its African Union (AU) partners. By 2016, China had become the largest troop contributor compared to its peers on the UN Security Council (the PLA maintains 2,510 troops on rotation compared to 93 for France, 336 for the UK, 98 for Russia, and 121 for the U.S.) with the vast majority serving in Africa (Huang, 2019). China is also the second-largest contributor to the UN peacekeeping budget, and the overall UN budget after the US (Lanteigne, 2018). In 2018 China took its peacekeeping missions further by channeling support towards building a logistics base for the Southern African Standby Force mechanism in Botswana and equipping the AU's Continental Logistics Base in Cameroon (Lanteigne, 2018).

China has accomplished several soft and hard power goals in its Africafocused peacekeeping engagement. First, it has strengthened its image as a "responsible big power" and provider of international public goods. Second, 
it has increased its influence in UN decision-making bodies, allowing it to shape mission mandates in ways that protect its strategic interests. Third, it has cultivated the image of a benign actor as it is mostly viewed as engaging in operations other than war. However, several less publicized hard power goals have also been advanced. For example PLA troops in the UN Mission in South Sudan protect oil installations and Chinese workers as part of their mandate. This is strategically important for China given that the oil infrastructure in South Sudan and Sudan is operated by Chinese state-owned companies (Ng and Agencies, 2014). In Mali, the PLA protects Chinese and foreign mission staff and critical infrastructure as part of its mandate with the UN mission there. Like South Sudan, Mali also hosts significant Chinese economic interests tied to the Belt and Road. Similar mandates are also in place for PLA peacekeepers in Sudan and the Democratic Republic of Congo, giving China an indirect means of extending its security presence in strategically important regions (Lanteigne, 2018).

The role Africa plays in accomplishing Chinese objectives on the global stage is consistent with the concept of: "Big powers are the key; China's periphery the priority; developing countries the foundation; and, multilateral platforms the stage (Chinese: 大国是关键, 周边是首要, 发展中国家是基 础, 多边是重要舞台), that has guided China's strategic mapping since the $\mathrm{Hu}$ Jintao era" (Sun, 2014). This principle is also reflected in China's institutional statecraft, which also blends soft and hard power objectives. In 2015, China created the UN Peace and Development Trust Fund, with an initial commitment of $\$ 10$ billion for use in global peace-making and peace-building (Nantulya, 2019). In 2017, it set up the China Africa Peace and Security Fund with an initial pledge of $\$ 100$ million for AU peacekeeping (Nantulya, 2019). That year it also placed an 8,ooo-strong Standby Force at the disposal of the UN Department of Peacekeeping Operations for use in crisis situations around the world (Nantulya, 2019). Such initiatives expand China's international diplomacy and leadership ambitions, consistent with its drive for Great Power status and its quest to "lead the reform of global governance." They also provide China a mix of flexible options to increase its African security footprint without relying on an overt PLA troop presence. This ability to blend soft and hard power tools in ways that amplify the former while downplaying the latter borrows heavily from China's strategic traditions. As explained in the third book of the "Seven Military Classics:"

The soft can control the hard; the weak can control the strong. The soft is virtue, the hard is brigand. The weak is what the people will help; the strong is what resentment will attack. The weak has situations in which 
it is applied; the strong has situations in which it is augmented. Combine these four and control them appropriately.

SAWYER, 1993

\subsection{Generating Sustained African Support for China's Vision of Transforming Global Governance}

At the 2018 Forum for China Africa Cooperation, China and its African partners agreed to "work together to promote the reform of the global governance system," and "build the community of common destiny" (Nantulya, 2020). The African common position on international reform is outlined in the AU's 2005 "Ezulwini Consensus" (African Union Commission, 2005). While it is much narrower that the Chinese position, China and the AU tend to view the current system as weighted against them, a shared grievance that makes Africa a "natural ally of China" to use the words of China's foreign minister, Wang Yi (Nagai, 2018).

African countries have indeed played significant roles in supporting Chinese efforts to reshape global institutions. In July 2019, the 43-member Africa Group at the World Trade Organization (WTO) joined China in adopting a resolution opposing U.S. veto power on appointments to the WTO's Appellate Body, the world's highest trade court (Miles, 2019). The African votes brought the number of WTO members opposed to the U.S. veto to 114, out of a membership of 163. African votes have also been critical in pushing several Chinese-sponsored resolutions in other areas such as human rights. Beijing's 2019 White Paper on Human Rights firmly rejects the liberal Western concept of human rights that centers on individual and civil liberties and political rights ("China issues White Paper", 2019). It instead prioritizes poverty reduction, economic, social, and cultural rights, and the expansion of welfare, an approach many African countries tend to champion when debating human rights, responding to criticism of their human rights records.

In 2015, China made 35 formal interventions at the Geneva-based UN Human Rights Council compared to 26 the previous year (Piccone, 2018). In 2017 it tabled its first-ever resolution titled, "The contribution of development to the enjoyment of all human rights." This was followed up in 2018 with another resolution, "Promoting mutually beneficial cooperation in the field of human rights" (Piccone, 2018: 13-22). Both documents promote noninterference, quiet dialogue, and the Chinese model of state-led development as the path to improving human rights and social stability. The 2017 resolution took the unprecedented step of inserting "Xi Jinping Thought" into UN language for the first time ever by recognizing the "Community of Common 
Destiny" as a contribution to global governance. It passed easily by a margin of 30 in favor, three abstentions, and 13 against despite vigorous opposition from America and several European countries. All 11 African members on the Council voted yes (Piccone, 2018). All but one African member voted yes for the 2018 resolution on "Promoting mutually beneficial cooperation" which also inserted language on the "Community of Common Destiny" ("UN rights body adopts resolution", 2019). Twenty-eight voted in favor while 17 abstained. America is the only country that voted no while its traditional allies, including Germany, United Kingdom, Australia, Japan, and Hungary abstained (Piccone, 2018).

China's long game to re-shape multilateral norms and institutions is occurring at a time when its chief rival, the U.S., has reduced its UN engagements. By 2018, Washington had withdrawn from the UN Human Rights Council and UN Educational Scientific and Cultural Organization (UNESCO) (Dwyer, 2018). In 2019, the U.S. proposed steep cuts to other UN agencies including the United Nations Development Program, UN High Commissioner for Refugees, and United Nations Department of Peacekeeping Operations. This was part of the Trump administration's proposal to cut America's foreign affairs budget by 23 percent (Hillard and Shendruk, 2019). China by contrast has increased its UN participation exponentially as part of a competitive strategy (Wintour, 2018). By 2019, four of the 15 specialized UN agencies were headed by Chinese nationals while U.S. nationals held only one (African nationals hold four) (Brett, 2019). In January 2019, Huang Xia, a veteran "Africanist" in the Chinese foreign ministry was appointed as the UN Secretary General's Special Envoy to the African Great Lakes Region, the first time a Chinese national has been appointed as a UN special envoy ("Secretary-General appoints Huang Xia", 2019).

Thanks to backing from the African regional bloc, Chinese nationals also hold the position of Deputy Special Representative (Political) for South Sudan and Deputy Head of the UN Mission in South Sudan, and the number two positions at the International Monetary Fund and International Court of Justice (Zhou, 2018). China, since 2007 has held the position of UN Undersecretary General for Economic and Social Affairs, a powerful post that oversees the UN's global development work. Beijing also has its sights on running the UN Department of Peacekeeping Operations, which has been headed by French nationals for the past two decades (Lynch, 2020).

This would be immensely strategic for China given that UN peacekeeping forces constitute the world's second largest expeditionary force of more than 100,000 troops (Lynch, 2020). The strong China/Africa partnership at the UN will be key if China opts to contest this post ("China-Africa cooperation", 2019). China has also leveraged its influence over the UN budget as part of its ongoing 
effort to re-shape UN organs. For example during the 2018/2019 UN budget negotiations, Beijing proposed cutting 170 human rights investigators within UN peacekeeping missions and the Office of the Secretary General (Piccone, 2018). With support from most African members, China also introduced proposals to reduce the number of non-governmental organization ( $\mathrm{NGO}$ ) observers at the UN Human Rights Council and decrease state cooperation with civil societies (Piccone, 2018). Although ultimately unsuccessful, these measures underscored China's assertiveness in re-shaping international institutions and its ability to enlist African support for its endeavors at the global level (Piccone, 2018).

\subsection{Soliciting African Support in Promoting Alternative Models and Development Paths}

One of China's most attractive and appealing selling points in Africa is its perceived success in transitioning from a poor country to a wealthy, powerful, and developed one in less than five decades. African counties have long been inclined to experiment with the Chinese model and many long-term development plans incorporate it as a guiding framework. These include Kenya's "Vision 2030," Rwanda's "Vision 2050," Uganda's "Vision 2040," and South Africa's "National Development Plan 2030" which all establish special economic zones, strong state-led development, rapid expansion of public works and infrastructure, targeted investments to increase livelihoods and reduce poverty, trade expansion, and export-driven growth (Nantulya, 2020). China's 2014 White Paper on Foreign Aid aligns Beijing's development assistance with these types of priorities, reflecting its own approach to development (Sun, 2014).

The African Union's “Agenda 2063: The Africa We Want" envisions Chinese expertise and models as key catalysts, as does the Program for Infrastructure Development in Africa (PIDA), an initiative of the African Development Bank (African Union Commission, 2013). At the 2018 FOCAC, Ghanaian President Nana Akuffo-Addo said: "Ghana is inspired by the China model and seeks to replicate it." South Africa's Cyril Ramaphosa said, "In the values China promotes, the manner it operates and the impact that it has on African countries, FOCAC refutes the view that a new colonialism is taking hold in Africa, as our detractors would have us believe" (Dahir, 2018). In April 2019, China and the AU established a China-Africa Institute in Beijing to facilitate policy synergy in developing "new models and mutual learning in governance and development" ("The China-Africa Institute established in Beijing", 2019) At its launching ceremony, Xi Jinping pledged that China, through this institute, would work with African states to "independently choose their own development paths" (Club of Mozambique, 2019). 
Beijing is heavily invested in increasing the popularity, appeal, and success of its models in Africa to increase its strategic influence on the continent and the rest of the developing world, validate its leadership on the world stage, reinforce its quest to promote workable "Chinese wisdom and solutions" as viable alternatives, and most importantly, to legitimize its governance system at home. Beijing also benefits heavily from the attraction and appeal of the larger Asian and Southeast Asian growth models on the continent, which are seen as being closely related to the Chinese model. As an indication, the Brenthurst Foundation's, 2020 top best-seller, The Asian Aspiration: Why and How Africa Should Emulate Asia, received more endorsements from serving and current African policymakers and economists than any other book since 2019 (Mills, Obasanjo, Desalegn, and Van der Merve, 2020).

The Afrobarometer $2013-2016$ results of a survey across 36 African countries found that China ranked a close second to the U.S. as a development model on the continent (Dionne K, 2016). Furthermore, the vast majority of Africans (63 percent) thought China's economic and political influence in their country was positive. As explained by United States Senator, Chris Coons (2018), "There is no other continent where the contest of ideas and systems between the United States is so widely and daily evident."

\section{A Sample of China's Growing Portfolio of Soft Power Tools}

Our country's underlying values hold greater appeal than ever before, and the wave of positive energy felt throughout society is building. We, the Chinese people, have greater confidence in our own culture. China's cultural soft power and the international influence of Chinese culture have increased significantly. There is greater unity in thinking both within the Party and throughout society. ${ }^{5}$

XI JINPING'S speech to the 19th CPC Congress in October 18, 2017

The core ingredients of China's overseas branding and image-building are evident in its African engagements. These are "attraction" (Chinese: 吸引力;

5 Jinping Xi, (2017, October 18) Secure a Decisive Victory in Building a Moderately Prosperous Society in All Respects and Strive for the Great Success of Socialism with Chinese Characteristics for a New Era Report Delivered at the 1gth National Congress of the Communist Party of China, Retrieved August 17, 2020 from https://www.chinadaily.com.cn/china/19thcp cnationalcongress/2017-11/o4/content_34115212.htm. 
Pinyin xī y̌̆n li) “appeal” (Chinese: 感召力; Pinyin: găn zhào li) and "Cultural Soft Power" (Chinese: 文化软实力; Pinyin: wén huà ruăn shí li). To secure African backing for its strategic goals on the global stage, Beijing has built a set of master narratives that it propagates continuously. First, China wants African audiences to believe that its resurgence as a global power is an inspiration to Africa and in the interest of African countries. Second, it wants Africans to look at it as an example of a country that found its own model of development without following Western prescriptions. Third, China wants Africans to see it as a genuine strategic partner uniquely sensitive to its needs as it too was once underdeveloped and colonized. These stories are reinforced through a wide range of soft power tools and platforms that have expanded at each three-year cycle of the Forum for China Africa Cooperation (FOCAC).

\subsection{International Education and Cultural Exchanges}

In 2000, when the first FOCAC took place, the Confucius Institute Headquarters (commonly known as Hanban) had no presence in Africa. By the fourth FOCAC in 2009, it had established around 70 Confucius Institutes in Africa ("Confucius Institutes", 2018). Presently, Hanban is second only to France's Alliance Français, in terms of the number of foreign cultural institutes around the world. By 2010, Hanban had overtaken the UK's British Council, Germany's Goethe Institute, and the State Department's American Centers (which have been operational in Africa since 1883, 1934, and 1960 respectively) (Lijadu, 2020). In 2000, less than 2,000 African students were studying in China, with around 40,000 choosing the United States and Canada, UK, India, and France. By 2018, this figure stood at 6o,ooo, a forty-four fold increase. China is now the second most popular destination overall (behind France) for African students (Victoria and Moore, 2007). China in 2018 offered 50,00o new scholarships for African students, 50,000 professional training programs, and 2,000 youth and student exchanges until 2021 and beyond. China, in 2018, also launched an AUChina scholarship for masters and doctoral students. The maximum age to access these opportunities is 35 years, indicating an interest by China to engage younger cohorts of African leaders and professionals (Muniu, 2019).

These exchanges have not been one sided: African students returning from China have established several Confucius Institute offshoots through private funding. Uganda's Luyanzi College - one the largest institutes for Chinese education in Africa - is among the most well-known (Hruby, 2018). It offers the 13-year Ugandan education curriculum entirely in Chinese.

It also trains Mandarin instructors as part of an initiative by the Uganda government to introduce Chinese in the education system, with the first batch 
of 34 instructors graduating in 2018 (Luedi, 2018). Similar programs have been introduced in more than a dozen African countries including Kenya, Senegal, and Nigeria. China has also offered an additional 10,0oo scholarships annually to Belt and Road citizens (McCarthy, 2018). By 2020, over 6o Chinese institutions were offering fully funded graduate and post-graduate programs for Belt and Road students, the bulk of whom come from Asia and Africa (McCarthy, 2018). This surge in higher education is meant to increase China's appeal and attraction in the eyes of African students, including self-sponsored ones. In 2013, there were 18,ooo self-sponsored African students in China compared to 12,000 on government schemes. From 2014, upwards of two-thirds of African students in China each year have been self-sponsored, suggesting that China's efforts to increase its "attraction capacity" seems to be succeeding beyond state-to-state agreements (Luedi, 2018).

\subsection{Shaping the Next Generation of African Leaders}

Beijing's political and leadership training programs showcase what it calls a "new type political system" (Fangfang, 2018). The CPC's theory of politics holds that Western democracy breeds "societal divisions," "endless transitions" and "social chaos" (Fangfang, 2018). Such themes are discussed in several venues such as the Central Party School and different platforms such as the "CPC in Dialogue with World Parties Series," China-Africa Political Party Forum and numerous Theory Seminars with ruling parties held throughout the year (Fangfang, 2018). These training packages are no longer limited to political movements with strong revolutionary ties to the CPC; they target African parties of all ideological stripes including opposition and political neutral groups (Sun, 2016). Over 400 party members attend them annually. The CPC has also moved some of this training to Africa to deepen its political work on the ground. One example is the Mwalimu Nyerere Leadership School in Tanzania, established through a $\$ 45$ million grant from the Communist Party's International Liason Department ("Leadership School for six African Countries Launched in Tanzania," 2018). It was founded by the Former Liberation Movements of Southern Africa, a grouping of the six liberation movements in power in Angola, Mozambique, Namibia, South Africa, Tanzania and Zimbabwe, which all had rear bases in Tanzania and enjoyed Chinese military support during their armed struggles. China's support for this school reinforces its image as a champion of Africa's liberation struggles, deepens China's ties to emerging elites, and increases its access to younger cohorts of future leaders. Over 400 young African politicians and cadres will be trained there annually (Gumede, 2018). 


\subsection{New Ventures}

China's soft power campaigns extend to youth, business, media, academia, and civil society, which were once considered off-limits due to Beijing's policy of non-interference. The China Africa Youth Festival and the China Africa Young Leaders Forum expose young Africans to leadership techniques, networking, sharing of experiences, and Chinese models of development and governance. Over 1,200 young African leaders have undergone such training since 2005 (Nantulya, 2018). China also provides local government capacity-building through the Forum on China Africa Local Government Cooperation, an arm of the Communist Party's Foreign Affairs Department.

Each year 10,00o African officials from the central government level to local governments and municipalities undergo training in service delivery, planning and budgeting, policy analysis, monitoring, and evaluation (Nantulya, 2018). China in recent years has also ventured into the African legal sector. The China Law Society, African Law Institute in Xiangtan University, and the Academy for International Business Officials within the Ministry of Commerce have trained over 40,00o young African lawyers since 2007 (Seppänen, 2008). The China-Asian-African Legal Consultative Forum provides an annual threeweek course on investments, special economic zones, and commercial dispute resolution ("The fifth training session", 2019). Similar programs are conducted by the Africa Young Legal Professionals Exchange Program, China Research Center on Legal Diplomacy, and China Africa Legal Cooperation Forum. These engagements are aimed at creating an enabling legal environment for Belt and Road projects, especially in the area of commercial dispute resolution (Jin, 2019).

China's soft power reach also extends to Africa's media space. Since 2014, over 1,00o African media professionals from over 40 countries have attended a 10-month Belt and Road media fellowship organized by the China Africa Press Center, a specialized agency of the Chinese foreign ministry (Zhang and Muthoni Mwangi, 2006). China's media outreach focusses on propagating its master narratives, promoting Chinese culture, and countering negative stories that have emerged around the Belt and Road, particularly on debt sustainability as African countries are taking on more debt to finance construction projects. The Chinese government has long viewed international broadcasting as a domain in the "battle of ideas." When cable news entered Africa in the 199os, China lagged far behind its Western competitors. By 2010, the stateowned Xinhua (now the world's biggest media outlet in terms of the number of correspondents) was employing more journalists in Africa than any other foreign media agency (Tyson, 2019). In 2018, it moved its Nairobi-based Africa Bureau into a 16-storey building, its first purpose-built office block outside 
China that also houses the Africa offices of China Global Television Network (CGTN) (Luedi, 2018).

Xinhua and CGTN are not the only Chinese players in Africa. Star Times, the only private Chinese media company authorized by the Chinese government to operate overseas, is Africa's second biggest provider of home-based digital television with over 10 million subscribers in 30 countries (Marsh, 2019). By 2025, it is expected to overtake South Africa's MultiChoice as the continent's largest digital television broadcaster. Xinhua's Nairobi bureau employs 150 journalists and 400 staff who generate and distribute 1,800 stories monthly, notably a much greater focus on Africa than BBC or CNN (Kahura, 2019). Also broadcasting from there is China Radio International's first overseas FM station with 19 hours of daily programming in Chinese, English, and Swahili. Xinhua also has a news exchange agreement with Kenya's Nation Media Group, the largest media house in East and Central Africa with 18 major brands (radio, television, and print) in four countries, 28 million social media followers, 11.3 million monthly page views, and 9o,ooo newspapers circulated daily (Nantulya, 2020).

Meanwhile China's media outreach in Africa has witnessed a shift from shortterm propaganda to shaping African media practices over the longer term, a strategy that got underway in the early 2ooos. Chinese voices have been replaced almost exclusively with African ones as part of this shift as seen through China's programming portfolio across several African multilingual platforms. For example, all the Africa-based products released by Xinhua's African Bureau (numbering over 21,00o annually) are authored by non-Chinese. Notably, they capture African nuances, making their pro-China messages more subtle. This type of nuance is also used by other Chinese media outlets in Africa and serves to ground Chinese stories within the larger African discourses.

\section{How Do Africans View China?}

China was my spiritual pillar during my life in prison. If you know the ways the Chinese people chose to carry out their revolution, you will believe that anything is possible. ${ }^{6}$

SOUTH AFRICAN PRESIDENT NELSON MANDELA during a conversation with his autobiographer, Richard Stengel

6 China Central Global Television (2018, July 18), Mandela: China is the Spiritual Pillar for me During my Life in Prison, CGTN, Retrieved August 17, 2020 from https://news.cgtn.com/news/ 3d3d414f3o63444f78457a6333566d54/share_p.html. 
This comment provides a glimpse into how many African leaders view China, at least in public. At the closing of the 6th FocAC in 2015, the late Zimbabwean leader, Robert Mugabe had this to say:

Here is a man [Xi Jinping] representing a country once called poor, which never was our colonizer; but he is doing to us what we expected those who colonized us yesterday to do. Let them hear!.

New China TV, 2015

Such loaded ideological themes reflect the larger tone of diplomatic communications between African and Chinese leaders and elites. When Kenyan foreign secretary Monica Juma tweeted her welcome of her Chinese counterpart to Mombasa in January 2020, she referred to him as her "brother" (Juma, 2020). Around the same time, Tanzanian foreign minister, Palamagamba Kabudi, called China a "close comrade and brother sharing weal and woe" in a condolence message to victims of COVID-19 in Hunan province (Ministry of Foreign Affairs of the People's Republic of China, 2020). ${ }^{7}$ African leaders rarely use such terms of endearment when dealing with their Western colleagues, indicating the highly personalized and intimate nature of their contacts with China. ${ }^{8}$ The 2016 Afrobarometer survey on African attitudes towards China found that Beijing's popularity among elites is generally shared by the public. Indeed, China matched the U.S. in popularity as a development model in Southern and Northern Africa. In Central Africa China took the lead (35 percent versus 27 percent for the United States) (Afrobarometer, 2016). It is worth noting however that China's strongest support in Africa comes from ruling political party elites, government executives, security sector officials, and private sector leaders with strong ties to governing elites. This is unsurprising given that China's engagements tend to be rooted in personal, political, and ideological ties to state actors (Carter, Gilpin, and Nantulya, 2019).

By contrast, Beijing's relationships with African civil society, independent academics, opposition activists, and human rights advocates are largely antagonistic and uneasy. China tends to view such groups as conduits of Western influence and regime change, a view shared by many African regimes (Carter, Gilpin, and Nantulya, 2019). African mainstream civil society coalitions in turn

7 Ministry of Foreign Affairs of the Peoples Republic of China (2020, January 2) Tanzanian FM Confident China Will Soon Prevail Over Novel Coronavirus, MFA, Retrieved August 17, 20202 from https://www.focac.org/eng/zfgx_4/zzjw/t1741197.htm.

8 See Pew Research Center's Global Indicators Database here: http://www.pewglobal.org/ database/indicator/24/group/5/. 
largely view China as a hindrance to the agenda of promoting accountable African governance (Vaes and Huyse, 2013). Increasingly, many of them avoid using Western language and terminology to oppose Chinese policies, choosing instead to invoke African documents such as the African Union Charter and African constitutions, to challenge claims that they represent Western interests.

Their central narrative is that China's unquestioned backing of authoritarian governments is at odds with African aspirations and inconsistent with Beijing's claim to be "all weather friend" of all Africans. China faces an uphill struggle in changing this perception. Although it has extended its reach into African civil society, professional bodies, media, and academia, its policy of "non-interference" means that its engagements with individuals and entities in these sectors are still regulated by state-to-state agreements. This also applies to China's highly sought-after scholarships, training opportunities, and grants which ruling authorities tend to use to coopt opponents and reward their loyalists, contributing to the widespread perception on the continent that Chinese assistance is bound up in local networks of corruption and patronage (Dreher et al., 2005).

For example in 2013 the Namibian media investigated a major scandal in which the government channeled Chinese scholarships to ruling party loyalists and family members. Despite the public outcry, and calls for an independent investigation, no one was held accountable (Ludei, 2018).

China's soft power image is also coming under increasing pressure from local private sector actors who feel overlooked in Belt and Road contracts, which are mostly designed to absorb Chinese capacity and technical knowhow (Sun, 2018). This was highlighted during the construction of the NairobiMombasa Standard Guage Railway, Kenya's most expensive infrastructure project since independence. In their field study on this project, Yuan Wang and Uwe Wissenbach (2019) found that most sub-contracts awarded by China Roads and Bridges Corporation went to firms with powerful political connections, including family members of some of Kenya's senior leaders (Wang and Wissenbach, 2009). They also found that a patron-client network was operational throughout the project cycle. In areas where trade unions, local businesses, and communities were included, the project was held accountable. The project was highly conducive to corruption when only elites were included (Wang and Wissenbach, 2009). Yuan and Wissenbach's study also noted that China Roads and Bridges Corporation preferred to keep out of Kenya's complicated local politics, leaving key decisions to the client, the Kenya Railways Corporation (KRC).

While this appears to have been a sound strategy the KRC is known to be one of the most corrupt public entities in Kenya according to parliamentary 
reports (Wang and Wissenbach, 2009). Indeed many of its senior executives were indicted by prosecutors for massive fraud, along with Chinese contractors and officials from other public institutions (Okoth, 2019). As more scandals were uncovered, angry debates erupted on social media, academia, and the private sector that not only undermined public trust in the government, but also dampened popular perceptions in Kenya about the Belt and Road and the Kenya/China partnership in general. In June 2020, the Kenya Court of Appeal ruled that the contract between Kenya and its Chinese partners over the railway was illegal (Nyabiage, 2020). This complaint was lodged in 2014 by Kenyan civil society activists and the Law Society of Kenya, one of the country's most respected and influential professional associations. China's image has also come under attack within Africa's organized labor movement. In South Africa the powerful Congress of South African Trade Unions, a partner the ruling African National Congress (one of China's closest partners) frequently organizes mass protests against what it calls the "dumping of cheap Chinese textiles into the country" ("China sews up", 2020). In 2017 it demanded the immediate deportation of Chinese workers after an independent investigation it sponsored found that a Chinese parastatal, Свм I Construction, allegedly brought in 242 Chinese nationals to work on a construction project (Allix, 2017).

Persistent concerns about the effects of cheap Chinese imports on local livelihoods has fueled numerous racially-charged attacks against Chinese nationals in more than a dozen African countries in recent years, including Angola, Cameroon, Gambia, Ghana, Lesotho, Malawi, Zambia, and South Africa. This violence is included in the 350 security incidents the Chinese Ministry of State Security says affected overseas Chinese between 2010 and 2015 (Goh, Martina, and Shepherd, 2017). 6o percent of these occurred in Africa in 2015 alone according to a report by the state-owned, The Paper (Solomon, 2020). These rising pockets of resentment undercut China's soft power influence on the continent, a problem compounded by the fact that China's most strategic investments tend to be concentrated in unstable countries. According to the Chinese Academy of Social Sciences, 84 percent of China's Belt and Road projects are in medium and high-risk countries (Devonshire-Ellis, 2020).

Chinese soft power advances in Africa are also increasingly being undermined by the glaring asymmetries in power between China and individual African countries. China since the mid-199os has been viewed on the continent as a world power in its own right, more so than a "fellow developing country" which is how Beijing prefers to be perceived. The relationship remains heavily titled in China's favor in several key areas. In her work on economic negotiations, Folashade Saule (2019) notes that African countries generally accept whatever terms are offered by their Chinese counterparts for fear that the 
money will go elsewhere or that they will offend Beijing and lose out in other areas of the relationship (Soule, 2019). China meanwhile at times flexes its economic power to get its partners to rescind decisions it finds disagreeable. For example in October 2018, the Chinese Embassy in Nairobi threatened to withhold funding for the extension of Kenya's Standard Guage Railway to retaliate a ban on Chinese fish imports (Gaitho, 2018). The then acting Ambassador, Li Xuhang, described this as a "trade war," one of the rare occasions when Beijing has publicly demonstrated its ability to employ coercive power in its dealings with African countries. With few funding options left, Kenya lifted the ban in February 2019 ("Kenya lifts China", 2019).

However, examples of African agency have emerged in recent years that have seen countries exploiting China's aversion to negative perceptions to increase their leverage. The tactics employed by Cote D'Ivoire in negotiating a $\$ 558$ billion energy agreement with Synohydro in 2017 are a case in point. The Ivorian government imposed a 20 percent cap on the labor the Chinese partner could import, committed it to sourcing all its construction materials locally, and stipulated that the working language would be French (Bloomberg, 2018). These demands were made clear from the start and negotiators stuck to their positions throughout ("China battles France", 2020). Each step of the negotiations was publicized to mobilize public opinion as a pressure tactic to incentivize the Chinese to be responsive to local demands. Tanzania used similar tactics in 2019 to re-negotiate the $\$ 11$ billion Bagamoyo megaport project with China Merchants Port Holdings International (См PHI). The original deal would have seen the Chinese partner secure a 99-year lease, zero duty on imported material, a commitment by Tanzania not to develop other ports that could compete with the project, and tax breaks for investors in a proposed special economic zone to be developed as part of the project (Waruru, 2019). The Tanzanian government flatly rejected the terms and made the details of the negotiations public to mobilize popular pressure against CMPHI. It described them as "unacceptable" and amounting to "selling Tanzania to the Chinese."

With the public firmly on its side, the government issued an ultimatum to the Chinese side demanding that it accept its counter-proposals or walk away ("Tanzania issues ultimatum", 2019). These were:

- A 33-year lease instead of 99

- No tax holiday

- No subsidized rates for water and electricity

- Full regulatory oversight of any businesses CMPHI introduced to the free trade zone

- No restriction of the Tanzanian government's right to develop other ports. 
The Chinese side agreed to the new terms in an effort to defuse public anger, allowing it to save face and salvage one of China's closest strategic relationships in Africa. Liberia offers yet another noteworthy example of African agency in China/Africa relations. The government put in place several institutional measures to maximize its negotiating power with external actors including through the vigorous enforcement of rules and regulations and robust parliamentary oversight and engagement. Notably, it also outsources all tenders to external independent firms as a strategy to reduce undue external influence on the contracting process ("Are Chinese infrastructure loans", 2019).

Soule (2018) identifies four conditions that African countries must meet to achieve greater balance in their relationships with China, particularly in infrastructure negotiations: 1) Involve the public at every stage, 2) Empower negotiators and technocrats, 3) Enhance oversight, and 4) Share experiences across country contexts (Soulé-Kohndou, 2018). All these are key given that China pays great attention to image and how its intentions are portrayed in public.

As this paper demonstrates, China has developed its own theory and practice of soft power that it has refined as part of its larger approach to statecraft. While soft power is mostly viewed as a Western construct, it has been a longstanding tradition in China with contending schools of thought and practice dating back to the Warring States Period, the root of Chinese philosophy. The Chinese approach to soft power stresses the cultural dimension and civilizational legacies much more than those offered by Western scholars, as it takes China's classical period as its reference point. This is described as "Cultural Soft Power" which views culture and cultural projection as essential resources for influence building based on Confucian/Mencian concepts of "appeal" and "attraction" and Legalist tenets of building the state's wealth and military power. "Cultural Soft Power" draws on traditions that have long considered Chinese culture and models to be superior and worthy of emulation by outsiders.

The Communist Party of China has instrumentalized these traditions to suit its political aims. It has brought soft power into the policy realm as a calculative strategy to strengthen its domestic regime, reinforce propaganda narratives, and create favorable international conditions to facilitate China's resurgence on the world stage. The promotion of Chinese norms, institutions, and models is one of the central features of this approach. The other key feature is the blending of soft and hard power instruments in ways that downplay underlying strategic intentions while bolstering China's image as a "responsible big 
power." The developing world, and Africa in particular, continue to be the central focus of China's international soft power campaigns. China's repertoire of soft power tools are primarily aimed at mobilizing strategic African support for Beijing's quest to re-shape global institutions, norms, and arrangements while building new ones. This is where Chinese soft power engagements have arguably had the most success, judging from African states' voting behavior in support of China' institution-shaping and norm-creation at the UN in particular.

A common criticism of Beijing's soft power approach is that it is top-down and state-driven. Geremie Barmé (2012) argues that the co-option of culture by governments is problematic, more so by authoritarian ones (Barmé, 2012). Ondřej Klimeš (2016) argues that China's soft power is compromised by the authoritarian nature of the CPC's governance (Klimeš, 2018). Others like David K. Schneider (2016), Sam Crane (2018), and Zhengyuan Fu (2017) argue that Legalist tenets, with all their authoritarian and power-maximizing undercurrents, are the center of gravity of the CPC intellectual traditions. Taken from this perceptive, China's soft power tools are decidedly Legalist in content and focus even though they are framed in Confucian/Mencian terms.

For many Western analysts, the top-down character of Chinese soft power means that what the CPC is selling overseas is essentially a projection of the party-state it has built at home, more so than a true reflection of Chinese cultural values. Many contemporary Chinese political thinkers and a few Western Sinologists like Martin Jacques (2011) dismiss this argument as a Western-centric judgment that fails to view China in its own terms ("Understanding China", 2012).

They argue that since China comes from a (largely Confucian) tradition in which the state is viewed as part of the family and society then it is not unusual for the Chinese government to articulate the country's cultural attributes and lead soft power initiatives. However, some Chinese writers sound a note of caution. Wang Jisi (2011), a leading Chinese soft power theorist suggests that China "will have to learn that soft power cannot be artificially created: such influence originates more from the society than the state" (Jisi, 2011: 12)

Others like Shi Yinhong (2007) argue that China cannot offer the world much value when it still has a long way to go to realize basic freedoms and rights (Yinhong, 2007). When examined from this perspective, the unattractiveness of China's political system will continue to undercut its international soft power appeal. However, China's leaders feel confident that their theory and practice of "Cultural Soft Power" has increased Beijing's ability to get African countries to want what it wants to paraphrase Joseph Nye, especially at the multilateral level. Furthermore, they believe that their strategic application of 
soft power has served their purpose of outmaneuvering their rivals for influence in Africa without flexing China's military muscles, advertising the PLA's military prowess, or using force, to paraphrase Sun Tzu.

\section{References}

Academy of Military Science Strategic Research Department. (2013). 军事科学院军事 战略研究部, 《战略学 2013 年版》 (北京: 军事科学出版社). [The Science of Military Strategy (2013 edition)]. Academy of Military Science Press.

African Union Commission. (2005). The common African position on the proposed reform of the United Nations: The Ezulwini consensus. Retrieved August 17, 2020, from https://www.un.org/en/africa/osaa/pdf/au/cap_screform_2005.pdf.

African Union Commission. (2013, June 10). Agenda 2063: The Africa we want. $A U$. Retrieved August 17, 2020, from https://au.int/en/agenda2063/overview.

African Union Commission. (2016, October 10). African Union signs agreement on Africa's high-speed railway network. AU Commission, Retrieved August 17, 2020, from https://au.int/en/pressreleases/20161010-2.

Afrobarometer. (2016, October 24,). China's growing presence in Africa wins largely positive popular reviews. Round 6 Dispatch, 122. Retrieved August 17, 2020, from http://afrobarometer.org/sites/default/files/publications/Dispatches/ab_r6_dispatchno122_perceptions_of_china_in_africa1.pdf.

Albert, E. (2018, February 5). China's big bet on soft power. Council on Foreign Relations. Retrieved August 17, 2020, from https://www.cfr.org/backgrounder/chinas-big -bet-soft-power.

Albert, E. (2018), China's big bet on soft power. Council on Foreign Relations. Retrieved August 16, 2020, from https://www.cfr.org/backgrounder/chinas-big-bet-soft-power. Allix, M. (2017, January 27). Cosatu cries foul over Asian workers. Business Day. Retrieved August 17, 2020, from https://www.businesslive.co.za/bd/business-and-eco nomy/2017-01-27-cosatu-cries-foul-over-asian-workers/.

American Academy of Political and Social Science, 6r6(1), p. 260.

Are Chinese infrastructure loans putting Africa on the debt-trap express? (2019, July 30). Belt \& Road News. Retrieved August 17, 2020, from https://www.beltan droad.news/2019/07/30/are-chinese-infrastructure-loans-putting-africa-on-the -debt-trap-express/.

Barker, T. (2017). The real source of China's soft power. The Diplomat. Retrieved August 16, 2020, from https://thediplomat.com/2017/11/the-real-source-of-chinas-soft-power/.

Barmé, G. (2012, May 1). Telling Chinese stories. Talk at the University of Sydney. The China Story. Retrieved August 17, 2020, from https://www.thechinastory.org/telling -chinese-stories/. 
Bloomberg. (2018, July 18) China battles France for business in its former African colonies. The Straits Times. Retrieved August 17, 2020 from https://www.straitstimes .com/world/africa/china-battles-france-for-business-in-its-former-african-colonies.

Brett, S. (2019, August 20). How the U.S. should address rising Chinese influence at the United Nations. The Heritage Foundation. Retrieved February 4, 2010, from https://www.heritage.org/global-politics/report/how-the-us-should-address -rising-chinese-influence-the-united-nations.

Campbell,J.(2018,June10). Global peacekeepingoperations overwhelminglyAfrican and in Africa. Council on Foreign Relations. Retrieved August 17, 2020, from https://www .cfr.org/blog/global-peacekeeping-operations-overwhelmingly-african-and-africa.

Canterbury Classics. (2016). The art of war and other classics of eastern philosophy. Printers Row Publishing Group.

Carter, P., Gilpin, R., \& Nantulya, P. (2019). China in Africa: Opportunities, challenges, and options. In S. McDonald and Michale C. Burgoyne (Eds.), China's global influence: Perspectives and recommendations. Daniel K Inouye Asia Pacific Center for Strategic Studies.

Chen, Zhi. (2004). From exclusive Xia to inclusive Zhu-Xia: The conceptualisation of Chinese identity in Early China. Journal of the Royal Asiatic Society 14(3), 185-205.

China-Africa cooperation boosts United Nations partnership with African Union, Secretary-General tells Security Council Ministerial Meeting UN. (2019, September 26). United Nations. Retrieved August 17, 2020, from https://www.un.org/ press/en/2019/sgsm19772.doc.htm.

China battles France for business in former African colonies. (2020, February 6). African Investor. Retrieved August 17, 2020, from https://www.africainvestor.com/ china-battles-france-for-business-in-former-african-colonies/.

China Central Global Television. (2018, July 18). Mandela: China is the spiritual pillar for me during my life in prison. CGTN. Retrieved August 17, 2020, from https://news .cgtn.com/news/3d3d414f3o63444f78457a6333566d54/share_p.html.

China issues White Paper on human rights progress over 70 years. (2019, September 9). Xinhua News. Retrieved August 17, 2020, from http://www.xinhuanet .com/english/2019-09/22/c_138412704.htm.

China sews up the textile market. (2005, June 30). Mail and Guardian. Retrieved August 17, 2020, from https://mg.co.za/article/2005-06-30-china-sews-up-the -textile-market.

Club of Mozambique. (2019, April 11). China unveils new forum to bolster Sino-Africa ties. Retrieved August 17, 2020, from https://clubofmozambique.com/news/ china-unveils-new-forum-to-bolster-sino-africa-ties/.

Confucius institutes a bedrock of China's growing cultural ties in Africa. (2018, August 23). China Daily. Retrieved August 17, 2020, from https://www.chinadaily .com.cn/a/2018o8/23/WS5b7e2ogaa31oadd14f38753c.html. 
Crane, S. (2018, June 28). Why Xi Jinping's China is legalist, not Confucian. China Channel, Retrieved August 17, 2020, from https://chinachannel.org/2018/o6/29/ legalism/.

Dahir, Abdi Latif. (2018, September 5). Satisfied and inspired: All the ways African leaders praised their alliance with China. Quartz Africa. Retrieved August 17, 2020, from https://qz.com/africa/1379457/china-africa-summit-african-leaders -praise-relations-with-beijing/.

Devonshire-Ellis, C (2020, July 20). 84\% Of China's BRI investments are in mediumhigh risk countries. Silk Road Briefing, Retrieved August 27, 2020, from https://www .silkroadbriefing.com/news/2020/o7/o2/84-chinas-bri-investments-medium-high -risk-countries/.

Dionne, Kim Yi (2016, October 28), Here's what Africans think about China's influence in their countries. Washington Post, Retrieved August 17, 2020 from, https:// www.washingtonpost.com/news/monkey-cage/wp/2016/10/28/heres-what -africans-think-about-chinas-influence-in-their-countries/.

Doherty, B. (2019, November 26). China leads world in number of diplomatic posts, leaving US in its wake. The Guardian. Retrieved August 17, 2020, from https://www.theguardian.com/world/2019/nov/27/china-leads-world-in-number -of-diplomatic-posts-leaving-us-in-its-wake.

Dreher, A., et al. (2005). Aid on demand: African leaders and the geography of China's foreign assistance. [Working Paper]. Center for Economic Studies and Ifo Institute, 5439 .

Dwyer, C. (2018, June 19). U.S. announces its withdrawal from U.N. Human Rights Council. National Public Radio. Retrieved August 17, 2020, from https:// www.npr.org/2018/o6/19/621435225/u-s-announces-its-withdrawal-from-u-n -s-human-rights-council.

Embassy of the People's Republic of China to Kenya. (2016, October 16). Ambassador Liu Guijin: China is not and will never be a "neocolonialist" in Africa. Chinese Mission. Retrieved August 17, 2020, from http://za.china-embassy.org/eng/zt/ask/t276318 .htm.

Fang, T. (2015). Yin yang: A new perspective on culture. Management and Organization Review, 8(1), 25-5o.

Fangfang, L. (2018, March 15). Homegrown and innovative: Multiparty cooperation and political consultation promote the values of democracy in the new era. Beijing Review, Retrieved August 17, 2020, from http://www.bjreview.com/Nation/201803/ t20180310_80o121547.html.

Finnish Institute of International Affairs. (2018, August 16), Xi Jinping thought and China's future foreign policy: Multipolarity with Chinese characteristics. FIIA Briefing Paper. Retrieved August 17, 2020, from https://www.fiia.fi/sv/publikation/ xi-jinping-thought-and-chinas-future-foreign-policy-3?read. 
Fu, S. (2011). Six records of a life adrift. Hackett Publishing Company Inc.

Fu, Zhengyuan. (2015). China's legalists: The earliest totalitarians and their art of ruling. Routledge.

Full report of $\mathrm{Hu}$ Jintao's report to the 17th Party Congress, Xinhua. (2007, October 24). Xinhua. Retrieved August 17, 2020, from https://www.chinadaily.com. cn/china/2007-10/24/content_6204564.htm.

Full text: China's national defense in the new era. (2019, October 2). Xinhua News. Retrieved August 17, 2020, from http://www.xinhuanet.com/english/2019-07/24/c -138253389.htm.

Full text of Xi Jinping's report at 19th CPC National Congress. (2017, November 3). Xinhua News Agency. Retrieved August 17, 2020, from http://www.xinhuanet.com/ english/special/2017-11/o3/c_136725942.htm.

Gaitho, M. (2018, October 30). China threatens to withhold SGR funds over 'hostility.' Daily Nation. Retrieved August 17, 2020, from https://www.nation.co.ke/kenya/ news/china-threatens-to-withhold-sgr-funds-over-hostility--104038.

Ghosh, P.K. (2009). The Chinese concept of comprehensive national power: An overview. Air Power Journal, 4(4), 17-54.

Goh, B, Martina, M. \& Shepherd, C. (2017, April 23). Local, global security firms in race along China's 'Silk Road.' Reuters. Retrieved August 27, 2020, from https://www .reuters.com/article/us-china-silkroad-security-analysis-idUSKBN17 P1oY.

Gramer, R. \& Lynch, C. (2009, March 11). Despite Pompeo's call for 'swagger,' Trump slashes diplomatic budget. Foreign Affairs. Retrieved August 17, 2020, from https://foreignpolicy.com/2019/o3/11/trump-federal-budget-steep-cuts-to-state -department-foreign-aid-development-diplomacy-pompeo/.

Green, W. (2020, August 22). Thanks Paul. There are a number of synergies between legalism and the CCP. [Tweet]. Twitter. https://twitter.com/PNantulya/with _replies.

Guangqian, P. (1998). Deng Xiaoping's strategic thought. In Pillsbury, M. (Ed.). Chinese views of future warfare. U.S. National Defense University Press.

Guangqian, P. \& Youzhi, Y. (2005). Science of military strategy. Military Science Publishing House.

Gumede, W. (2018, August 23). How China is changing democracy in Africa. News 24. Retrieved August 17, 2020, from https://www.news24.com/Columnists/Guest Column/how-china-is-changing-democracy-in-africa-20180823.

Hillard, L. \& Shendruk, A. (2019, April 2). Funding the United Nations: What impact do U.S. contributions have on UN agencies and programs? Council on Foreign Relations. Retrieved August 17, 2020, from https://www.cfr.org/article/funding-united-nations -what-impact-do-us-contributions-have-un-agencies-and-programs.

Ho, Ping-Ti. (1962). The ladder of success in imperial China aspects of social mobility, 1368-1911. Columbia University Press. 
Holt, Victoria K. \& Shanahan, Moira K. (2005). African capacity-building for peace operations: UN collaboration with the African Union and Economic Community of West African States (ecowas). The Henry L. Stimson Center, Retrieved August 17, 2020, from https://www.stimson.org/wp-content/files/file-attachments/African_Ca pacity-building_1.pdf.

Hruby, D. (2018, September 30). The interracial couple championing China's soft power in Africa. South China Morning Post. Retrieved August 17, 2020, from https://www .scmp.com/magazines/post-magazine/long-reads/article/2164953/interracial -couple-championing-chinas-soft-power.

Hu Jintao Speech to Literary and Art Circles Remin Ribao. (2006, November 2). Renmin Ribao. [Peoples Daily].

Huaidong, P. (1997). Lun zhan Xi Zhan-Zhong guan zhi yancha yi, [On the basic differences between Chinese and Western viewpoints on war], China Military Science, $1(127)$.

Huang, C. (2019, October 2). Peacekeeping contributor profile: The People's Republic of China. Providing for Peacekeeping. Retrieved August 17, 2020, from http://www .providingforpeacekeeping.org/2014/04/o3/contributor-profile-china/.

Huning, W. (1993). Zuowei guojia shili de wenhua: Ruan quanli [Culture as national power: Soft power]. Fudan Daxue Xuebao, 3 .

Hutton, Eric L. (2004). Xunzi: The complete text. Princeton University Press.

Ikenberry, John G. \& Lim, D. (2007). China's emerging institutional statecraft: The Asian infrastructure investment bank and the prospects for counter-hegemony. Brookings Institution. Retrieved August 17, 2020, from https://www.brookings.edu/ wp-content/uploads/2017/o4/chinas-emerging-institutional-statecraft.pdf.

Jiechi, Y. (2017). Study and implement General Secretary Xi Jinping's thought on diplomacy in a deep-going way and keep writing new chapters of major-country diplomacy with distinctive Chinese features. Xinhua. Retrieved August 16, 2020, from http://www.xinhuanet.com/english/2017-07/19/c_136456oog.htm.

Jiechi, Y. (2019). Advancing China's major-country diplomacy under the guidance of Xi Jinping thought on foreign affairs, QiushiJournal, 11(4).

Jijun, Li. (1997) Zhongguo junshi sixiang chuantong yu fangyu zhanlue, [On traditional military thinking and the defense strategy of China] China Military Science, 4 , $62-64$.

Jin, Z. (2019, October 15). China to enhance legal exchanges, build cooperation platforms with B RI countries. China Daily, Retrieved August 17, 2020, from http://www .chinadaily.com.cn/a/201910/15/WS5da5739oa31ocf3e355709c7.html.

Jinping, Xi. (2014). Enhance China's cultural soft power, in the Governance of China. People's Republic Foreign Languages Press.

Jisi, W. (2011). China's search for a grand strategy: A rising great power finds its way. Foreign Affairs, 9o(2), pp. 68-79. 
Jones, David G. (2012). The meaning of Bing-fa (often referred to as Sun Tzu: The Art of War), Retrieved August 16, 2020, from https://shibumimanagementcanada.wordpress.com/2012/o6/o2/the-meaning-of-ping-fa-often-referred-to-as-sun-tzu-the -art-of-war/.

Juma, Monica. 2020, January 10. Today I received my brother Hon. Wang Yi, State Councillor and Minister of Foreign Affairs of the People's Republic of China at the Moi International Airport, Mombasa. [Tweet]. Twitter. https://twitter.com/CSDefence _Kenya/status/1215628476465713155.

Jung, C. (1961). Wild swans: Three daughters of China. Simon \& Schuster.

Kahura, D. (2019, May 2). Enter the dragon: China's media war in Africa. The Elephant. Retrieved August 17, 2020, from https://www.theelephant.info/features/2019/05/O2/ enter-the-dragon-chinas-media-war-in-africa/.

Keane, M. \& Jing Zhao, E. (2014). The reform of the cultural system: Culture, creativity and innovation in China. In H. Lee \& L. Lim (Eds.), Cultural policies in East Asia: Dynamics between the state, arts, and creative industries (pp. 155-173). Palgrave Mc Millan.

Kenya Lifts China Fish Ban To Boost Supply. [Editorial]. (2019, February 17). Daily Nation Retrieved August 17, 2020, from https://www.nation.co.ke/business/Keny a-lifts-China-fish-ban-to-boost-supply/996-4986328-cvnjw3/index.html.

Klimeš, O. (2018). China's cultural soft power: The central concept in the early Xi Jinping era (2012-2017). AUC PHILOLOGICA, 2017, 127-150. https://doi .org/10.14712/24646830.2017.45.

Klimeš, O. (2018). China's cultural soft power: The central concept in the early Xi Jinping era (2012-2017). Acta Universitatis Carolinae, 4, pp. 127-15o.

Lanteigne, M. (2018). The role of UN peacekeeping in China's expanding strategic interests. United States Institute of Peace.

Leadership school for six African countries launched in Tanzania. (2018, July 17). Xinhua. Retrieved August 17, 2020, from http://www.xinhuanet.com/english/2018 -07/17/c_137329281.htm.

Legarda, H. (2018, March 20). China upgrades diplomacy while the US pulls back. The Diplomat. Retrieved August 17, 2020, from https://thediplomat.com/2018/03/ china-upgrades-diplomacy-while-the-us-pulls-back/.

Lexiong, N. (2000). Zhanzhengyu wenhua chuantong: Dui lishi de ling yi zhong guancha [War and cultural tradition: Another perspective on history]. Guji Publishing House.

Li, B. \& Zheng, Y. (2001). 中华五千. [50oo Years of Chinese History]. Inner Mongolian People's Publishing.

Li, H. (2015). The Chinese model of development and its implications. World Journal of Social Science Research, 2(2), 128-138.

Li, X. \& Worm, V. (2010). Building China's soft power for a peaceful rise. Journal of Chinese Political Science/Association of Chinese Political Studies, 16, 69-89. 
Lijadu, K. (2020, February 5). China's language and cultural centers are growing faster across Africa than we thought. Quartz Africa. Retrieved August 17, 2020, from https:// qz.com/africa/1351749/chinas-confucius-institutes-in-africa-spread-mandarin -culture/.

Liu, H. (2015). The Chinese strategic mind. Elgar Publishing.

Lo, K. (2017). Wang Huning, the low-profile, liberal dream weaver who's about to become China's ideology tsar. South China Morning Post. Retrieved August 17, 2020 from https://www.scmp.com/news/china/policies-politics/article/2116964/ wang-huning-low-profile-liberal-dream-weaver-whos-about.

Luedi, J. (2018, October 18). Why African students are choosing China over the West. Asia by Africa. Retrieved August 17, 2020, from https://www.asiabyafrica.com/ point-a-to-a/african-international-students-study-in-china.

Lynch, C. (2020, February 4). China eyes ending Western grip on top U.N. jobs with greater control over Blue Helmets. Foreign Policy. Retrieved August 17, 2020, from https://foreignpolicy.com/2016/10/o2/china-eyes-ending-western-grip-on-top-u-n -jobs-with-greater-control-over-blue-helmets/.

Marsh, J. (2019, July 24). How China is slowly expanding its power in Africa, one TV set at a time. Cable News Network. Retrieved August 17, 2020, from https://www.cnn .com/2019/o7/23/business/startimes-china-africa-kenya-intl/index.html.

Matanda, D. (2019). China's Belt and Road initiative and Africa - An Interview with Paul Nantuly., Habari News. Retrieved August 16, 2020, from http://www.thehabari network.com/chinas-belt-and-road-initiative-and-africa.

Mattis, P (January 2018), China's three warfares in perspective. War on the Rocks. Retrieved August 15, 2020, from https://warontherocks.com/2018/o1/chinas-three -warfares-perspective/.

Mc McCarthy, S. (2018, September 27). Why foreign students along the Belt and Road are jostling to enroll in China's universities. South China Morning Post. Retrieved August 17, 2020, from https://www.scmp.com/news/china/society/article/2165892/ why-foreign-students-along-belt-and-road-are-jostling-enrol.

Mc Vadon, E. (2011). The PLA Navy as an instrument of statecraft. In Philip C. Saunders, Swaine Michael Yung, Christopher, \& Andrew Nien-Dzu Yang (Eds.), The Chinese Navy: Expanding capabilities, evolving roles (pp. 215-241). National Defense University Press.

Miles, T. (2019, June 26). African nations join majority in opposing U.S. blockage at wTO. Reuters. Retrieved August 17, 2020, from https://www.reuters.com/article/ us-usa-trade-wto-africa/african-nations-join-majority-in-opposing-u-s-blockage -at-wto-idUSKCNiTRıWH.

Mills, G, Obasanjo O, Desalegn, H, and Van de Merwe E, The Asian Aspiration: Why and How Africa Should Emulate Asia, Brenthurst Foundation (2020). 
Muniu, G. (2019, March 11). Scholarships help cultivate future leaders of Africa. China Daily. Retrieved August 17, 2020, from https://www.chinadaily.com.cn/a/201903/11/ WS5c89b9cea3106c65c34ee951.html.

Murphy, Z. (2010, July 28). Zheng He: Symbol of China's 'Peaceful rise.' BBC. Retrieved August 17, 2020, from https://www.bbc.com/news/world-asia-pacific-10767321.

Nagai, O. (2018, September 4). China pledges another $\$ 6$ obn to Africa in bid to win allies. Nikkei Asian Review. Retrieved August 17, 2020, from https://asia.nikkei.com/ Politics/International-relations/China-pledges-another-6obn-to-Africa-in-bid-to -win-allies.

Nantulya, P. (2012). China's strategic application of soft power and implications for U.S. national security. [Unpublished fieldwork]. Missouri State University Department of Defense and Strategic Studies.

Nantulya, P. (2016). Remove the firewood from under the pot: 釜底抽薪 Fǔ dı̌ chōu xin: Assessing how the Chinese are likely to respond to the U.S. military concept of air sea battle through a Chinese traditional strategic culture lens. [Unpublished fieldwork]. Missouri State University Department of Defense and Strategic Studies. Nantulya, P. (2018, August 30). Grand strategy and China's soft power push in Africa. Africa Center for Strategic Studies. Retrieved August 17, 2020, from https://africacenter.org/spotlight/grand-strategy-and-chinas-soft-power-push-in-africa/.

Nantulya, P. (2019, January 17). Chinese hard power supports its growing strategic interests in Africa. Africa Center for Strategic Studies. Retrieved August 17, 2020, from https://africacenter.org/spotlight/chinese-hard-power-supports-its-growing-stra tegic-interests-in-africa/.

Nantulya, P. (2019, March 22). Implications for Africa from China's One Belt One Road strategy. Africa Center for Strategic Studies. Retrieved August 17, 2020, from https://africacenter.org/spotlight/implications-for-africa-china-one-belt-one-road -strategy/.

Nantulya, P. (2020, May 20). Testimony before the U.S.-China Economic and Security Review Commission hearing on: China's strategic aims in Africa. Retrieved August 17, 2020, from https://www.uscc.gov/sites/default/files/Nantulya_Testimony.pdf.

New China TV. (2015, December 4). Robert Mugabe expresses gratitude to China at China-Africa summit. [YouTube Channel]. Retrieved August 17, 2020, from https:// www.youtube.com/watch?v=WJYPZtxsMdU.

New starting point, new vision and new journey - Wang Yi on outcomes of the second belt and road forum for international cooperation (BRF). (2019, April 29). Ministry of Foreign Affairs of the Peoples Republic of China. Retrieved August 17, 2020, from https://www.fmprc.gov.cn/mfa_eng/zxxx_6628o5/t166o86o.shtml.

Ng, T. \& Agencies. (2014, September 10). China deploys 700 troops to UN force to protect South Sudan oilfields. South China Morning Post, Retrieved August 17, 2020, from 
https://www.scmp.com/news/china/article/1589210/china-deploys-70o-troops-un -force-protect-south-sudan-oilfields .

Nyabiage, J. (2020, June 23). Contract for Kenya's China-funded railway ruled 'illegal.' South China Morning Post. Retrieved August 17, 2020, from https://www.scmp.com/ news/china/diplomacy/article/3090225/contract-kenyas-china-funded-railway -ruled-illegal.

Nye Jr, Joseph S. (1990). Bound to Lead: The Changing Nature of American Power. Basic Books.

Nye Jr, Joseph S. (2004). Soft Power: The Means to Success in World Politics. Perseus Books Group.

Okoth, E. (2019, June 9). Shocking details of mysterious local owners of s GR firm. Daily Nation. Retrieved August 17, 2020, from https://www.nation.co.ke/news/Shockin g-details-of-mysterious-local-owners-of-SGR-firm/1056-5150128-yiesvlz/index.html. Phillips, T. (2016). China breaks official silence on Cultural Revolution's Decade of Calamity. The Guardian. Retrieved August 16, 2020, from https://www.theguardian .com/world/2016/may/17/cultural-revolution-reduced-to-footnote-as-communist -party-says-china-has-moved-on.

Piccone, T. (2018). China's long game at the United Nations. Brookings Institution.

Pines, Y. (2006). Legalism in Chinese philosophy. In The Stanford Encyclopedia of Philosophy, Retrieved August 15, 2020, from https://plato.stanford.edu/entries/ chinese-legalism/.

PLA implements new political work regulation. (2010, September 3). Peoples Daily Retrieved August 15, 2020 from, http://en.people.cn/90oo1/90776/7139024.html.

PLA National Defense University. (2006). The science of campaigns. PLA Press.

President Xi proclaims Silk Road spirit. (2019, October 1). Xinhua News. Retrieved August 17, 2020, from http://www.xinhuanet.com/english/2017-05/14/c_136281622 .htm.

Sawyer, Ralph D. (1993) The Seven Military Classics of Ancient China. Basic Books.

Sawyer, Ralph D. (1996). One hundred unorthodox strategies: Battles and tactics of Chinese warfare. Westview Press.

Sawyer, Ralph D. (2006). Chinese strategic power: Myths, intent, and projections, Journal of Military and Strategic Studies, $9(2)$.

Sawyer, Ralph D. \& Sawyer, M. (2009). Ancient Chinese warfare. Perseus Books.

Schneider, David K. (2016). China's new legalism. The National Interest, 143, pp. 19-25.

Scobell, A. (2002). China and strategic culture. U.S. Army War College Press.

Secretary-General appoints Huang Xia of China Special Envoy for Great Lakes Region. (2019, January 22). United Nations. Retrieved August 17, 2020, from https://www .un.org/press/en/2019/sga1851.doc.htm.

Seppänen, S. (2008). Chinese legal development assistance: Which rule of law? Whose pragmatism? Venderbilt Journal of Transnational Law, 5 . 
Shambaugh, D. (2015). China's soft-power push: The search for respect. Foreign Affairs. Retrieved August 17, 2020, from https://www.foreignaffairs.com/articles/ china/2015-o6-16/china-s-soft-power-push.

Soft power: China takes measures to bolster its global cultural prowess. (2007, December 19). China Media Project. Retrieved August 17, 2020, from http://cmp.hku .hk/2007/12/19/797.

Solomon, S. (2020, March 4). Coronavirus brings ‘sinophobia’ to Africa. Voice of America. Retrieved August 17, 2020, from https://www.voanews.com/science-health/corona virus-outbreak/coronavirus-brings-sinophobia-africa.

Soulé-Kohndou, F. (2018). Bureaucratic agency and power asymmetry in Benin-China relations. In C. Alden \& D. Large (Eds.), New directions in Africa-China studies. Routledge. https://doi.org/10.4324/9781315162461.

Soule, F, (2019, January 3). How to negotiate infrastructure deals with China: Four things African governments need to get right. The Conversation. Retrieved August 17, 2020, from https://theconversation.com/how-to-negotiate-infrastructure-deals-with -china-four-things-african-governments-need-to-get-right-1o9116.

Spence, D. (2011). Kissinger and China. China file. Retrieved August 16, 2020, from https://www.chinafile.com/library/nyrb-china-archive/kissinger-and-china.

State Council Information Office. (2005, December 2). China's peaceful development road. State Council. Retrieved August 17, 2020, from http://english.www.gov.cn/ archive/white_paper/2014/og/og/content_281474986284646.htm.

State Council Information Office. (2019). China and the world in the new era. Retrieved August 16, 2020, from http://english.www.gov.cn/archive/whitepaper/2019o9/27/ content_WS5d8d8ofgc6dobcf8c4c142ef.html.

State Council Information Office. (July 2019). [国务院新闻办公室] China's national defense in a new era [新时代的中国国防]. Retrieved August 15, 2020 from, http://www .xinhuanet.com/politics/2019-07/24/c_112479245o.htm.

Sun, Y. (2014). Africa in China's foreign aid. Brookings Institution.

Sun, Y. (2014). Africa in China's foreign policy. Brookings Institution.

Sun, Y. (2016, July 5). Political party training: China's ideological push in Africa? Brookings Institution. Retrieved August 17, 2020, from https://www.brookings.edu/ blog/africa-in-focus/2016/o7/o5/political-party-training-chinas-ideological-push -in-africa/.

Sun, Y. (2018, July 11). American companies and Chinese Belt and Road in Africa. Brookings Institution. Retrieved August 17, 2020, from https://www.brookings.edu/ blog/africa-in-focus/2018/o7/11/american-companies-and-chinese-belt-and-road -in-africa/.

Szczepanski, Kallie. (2015). What is the mandate of heaven in China? About Education. Retrieved August 17, 2020, from https://www.thoughtco.com/the-man date-of-heaven-195113. 
Tanzania issues ultimatum to China merchant holdings over \$1bn Bagamoyo project. (2019, October 23). Global Construction Review. Retrieved August 17, 2020, from https://www.globalconstruction review.com/news/tanzania-issues-ultimatum -china-merchant-holdings-/.

Tanzanian FM confident China will soon prevail over novel coronavirus. (2020, January 2). Ministry of Foreign Affairs. Retrieved August 17, 2020, from https://www .focac.org/eng/zfgx_4/zzjw/t1741197.htm.

Taylor, A. (2019, September 10). Mattis compared Xi's China to the Ming Dynasty. Xi might be happy to hear it. Washington Post. Retrieved August 17, 2020, from https://www.washingtonpost.com/news/worldviews/wp/2018/o6/20/mattis -compared-xis-china-to-the-ming-dynasty-xi-might-be-happy-to-hear-it/.

Teijun, Z. (2012). Chinese strategic culture: Traditional and present features, Comparative Strategy, 21(2).

The China-Africa Institute established in Beijing: Yang Jiechi reads the congratulatory message from President Xi Jinping and delivers a speech. (2019, April 4). Ministry of Foreign Affairs. Retrieved August 17, 2020 from https://www.fmprc.gov.cn/mfa_eng/ zxxx_6628o5/t1654342.shtml.

The fifth training session of China-Asian-African Legal Consultative Organization (AALCO) exchange and research program on international law held in China. (2019, August 6). Ministry of Foreign Affairs of the People's Republic of China. Retrieved August 17, 2020, from https://www.fmprc.gov.cn/mfa_eng/wjbxw/t1687172 .shtml.

Tingyang, Z. (2005). 赵汀阳, Tianxia Tixi: Shijie zhidu zhexue daolun 天下体系：世界 制度哲学导论 [The Tianxia system: An introduction to the philosophy of a world institution]. Jiangsu Jiaoyu Publishing Company.

Tingyang, Z. (2009) 赵汀阳, Huai Shijie Yanjiu: Zuowei diyi zhexuede zhengzhi zhexue (坏世界研究: 作为第一哲学的政治哲学) [Investigations of the bad world: Political philosophy as the First Philosophy]. Renmin Daxue Publishing Company.

Tingyang, Z. (2018, February 7). Can this ancient Chinese philosophy save us from global chaos? The Washington Post. Retrieved August 17, 2020, from https://www .washingtonpost.com/news/theworldpost/wp/2018/o2/o7/tianxia/.

Tobin, L. (2018). Xi's vision for transforming global governance: A strategic challenge for Washington and its allies. Texas National Security Review, The Strategist, 2(1).

Tyson, A. (2019, July 3). China is ramping up its media abroad - and not just in Chinese. Christian Science Monitor. Retrieved August 17, 2020, from https://www .csmonitor.com/World/Asia-Pacific/2019/o703/China-is-ramping-up-its-media -abroad-and-not-just-in-Chinese.

UN rights body adopts resolution on development submitted by China. (2019, July 13). Xinhua. Retrieved August 17, 2020, from http://www.xinhuanet.com/english/2019 -07/13/c_138222020.htm. 
Understanding China and its rise: The 'civilization-state.' (2010, July 31). Asia Society. [Talk at the Asia Society.] Retrieved August 17, 2020, from https://asiasociety.org/ india/understanding-china-and-its-rise-civilization-state.

U.S. China Economic and Security Review Commission. (2017). China's high speed rail diplomacy. USCC. Retrieved August 17, 2020, from https://www.uscc.gov/research/ chinas-high-speed-rail-diplomacy.

Vaes, S. \& Huyse, H. (2013). New voices on south south cooperation between emerging powers and Africa: African civil society perspectives. Research Institute for Work and Society.

Victoria, B. \& Moore, N. (2007, June 30), China has overtaken the US and UK as the top destination for anglophone African students. Quartz Africa. Retrieved August 17, 2020, from https://qz.com/africa/1017926/china-has-overtaken-the-us-and-uk-as -the-top-destination-for-anglophone-african-students/.

Wade, G. (2005). The Zheng He Voyages: A reassessment. Journal of the Malaysian Branch of the Royal Asiatic Society, 78(1), 37-58.

Wang, Y. (2008.) Public diplomacy and the rise of Chinese soft power. The Annals of the American Academy of Political and Social Science, 616(1), 260.

Wang, Y. (2011). Harmony and war: Confucian culture and Chinese power politics. Columbia University Press.

Wang, Y. \& Wissenbach, U. (2009). Clientelism at work? A case study of Kenyan standard Gauge railway project. Economic History of Developing Nations, 34(3).

Waruru, M. (2019, December 3). Will East Africa sail off into the sunset with its economy-boosting port projects, or are there clouds on the horizon? Equal Times. Retrieved August 17, 2020, from https://www.equaltimes.org/will-east-africa-sail -off-into-the\#.XecnBOhKjec.

Wei-ming, T. (1991). Cultural China: The periphery as the center. Daedalus, 120(2), 1-32. Retrieved August 16, 2020, from www.jstor.org/stable/20025372.

Wintour, P. (2018, September 24). China starts to assert its worldview at UN as influence grows.TheGuardian. RetrievedFebruary4,2020,fromhttps://www.theguardian.com/ world/2018/sep/24/china-starts-to-assert-its-world-view-at-un-as-influence-grows.

$\mathrm{Wu}, \mathrm{Y} .(2018)$. The rise of China with cultural soft power in the age of globalization.Journal of Literature and Art Studies, 8. https://doi.org/10.17265/2159-5836/2018.05.006.

Xi, Jinping. (2017, October 18). Secure a decisive victory in building a moderately prosperous society in all respects and strive for the great success of socialism with Chinese characteristics for a new era. Report Delivered at the 19th National Congress of the Communist Party of China, Retrieved August 17, 2020, from https://www.chi nadaily.com.cn/china/19thcpcnationalcongress/2017-11/o4/content_34115212.htm.

Xi: China to contribute wisdom to global governance. (2016, July 1). Xinhua News. Retrieved August 16, 2020, from https://www.chinadaily.com.cn/china/2016-o7/o1/ content_25933506.htm. 
Xie, Tao. (2015). China's soft power obsession. The Diplomat, Retrieved August 15, 2020, from https://thediplomat.com/2015/o4/chinas-soft-power-obsession/.

Xing Ye, Z. \& Zhan Li, Z. (Eds.). (2002). Campaign stratagems. National Defense University Publishing House.

Xinhua News Agency. (2011). Full text of Xi Jinping's report at 19th CPC National Congress. China Daily. Retrieved August 16, 2020, from https://www.chinadaily .com.cn/china/19thcpcnationalcongress/2017-11/o4/content_34115212.htm.

Xintian, Y. (2008). Ruan shili jianshe yu Zhongguo duiwai zhanlue, [Soft power development and China's foreign strategy]. Zhongguo yu shijie zhuanlun [Forum on China and the World ], 2(17).

Xuetong, Y. (2001). The rise of China in Chinese eyes. Journal of Contemporary China, $10(26)$.

Yang Yue Heng, S. (2020, February 13). Belt \& Road initiative: A big concept. China and U.S. focus. Retrieved August 17, 2020, from https://www.chinausfocus.com/ finance-economy/belt--road-initiative-a-big-concept.

Yang, Y. \& Jingyi, L. (2019, April 21). Djibouti: Chinese military's first overseas support base. China Global Television. Retrieved August 17, 2020, from https://news.cgtn .com/news/3d3d514d7859544d34457a6333566d54/index.html.

Yinhong, S. (2007). China's soft power and peaceful rise. Zhongguo Pinglun, 118, pp. $24-38$.

Yunshan, L. (2002, December 11). Tuidong Zhongguo tese shehuizhuyi wenhua de fazhan fanrong, [Promote the development and prosperity of socialist culture with Chinese characteristics]. Zhongguo Wang. Retrieved August 3, 2020 from, http:// www.china.com.cn/chinese/zhuanti/244819.htm.

Yunshan, Liu. (2002, December 11). Hold High the Banner of Advanced Culture. Renmin Ribao [People's Daily].

Zedong, M. (1960). On protracted war. In Selected Works of Mao Zedong. People's Publishing House.

Zegart, A. (2019). Decades of being wrong about China should teach us something. The Atlantic. Retrieved August 17, 2020, from https://www.theatlantic.com/ideas/ archive/2019/06/30-years-after-tiananmen-us-doesnt-get-china/591310/.

Zhang, T. (2002). Chinese strategic culture: Traditional and present features. Comparative Strategy, 21(2).

Zhang, W. (2008). The Yellow Register Archives of Imperial Ming China. Libraries \& the Cultural Record, 43(2), 148-175. Retrieved August 17, 2020, from www.jstor.org/ stable/25549473.

Zhang, W. (2010) China's cultural future: From soft power to comprehensive national power. International Journal of Cultural Policy, 16(4). 
Zhang, Y. and Muthoni Mwangi, J. (2006). A perception study on China's media engagement in Kenya: From media presence to power influence? Chinese Journal of Communication, 9 .

Zhao, D. (October 2015). The confucian-legalist state: A new theory of Chinese history. Oxford University Press.

Zhengyuan, F. (2015) China's legalists: The early totalitarians and their art of ruling. Routledge.

Zhou, L, (2018, October 8) Which Chinese hold top jobs at key international bodies? South China Morning Post Retrieved August 17, 2020, from https://www.scmp .com/news/china/diplomacy/article/2167522/which-chinese-hold-top-jobs -key-international-bodies.

奈, 美国定能领导世界吗, 军事译文出版社. (1992). [America Joseph Nye, Can America Lead the World?]. Military Translation Publishing House. Official Translation. 